Prepared in cooperation with the U.S. Environmental Protection Agency Region 4 Superfund Section

\title{
Continued Geophysical Logging Near the GMH Electronics National Priorities List Superfund Site Near Roxboro, North Carolina
}

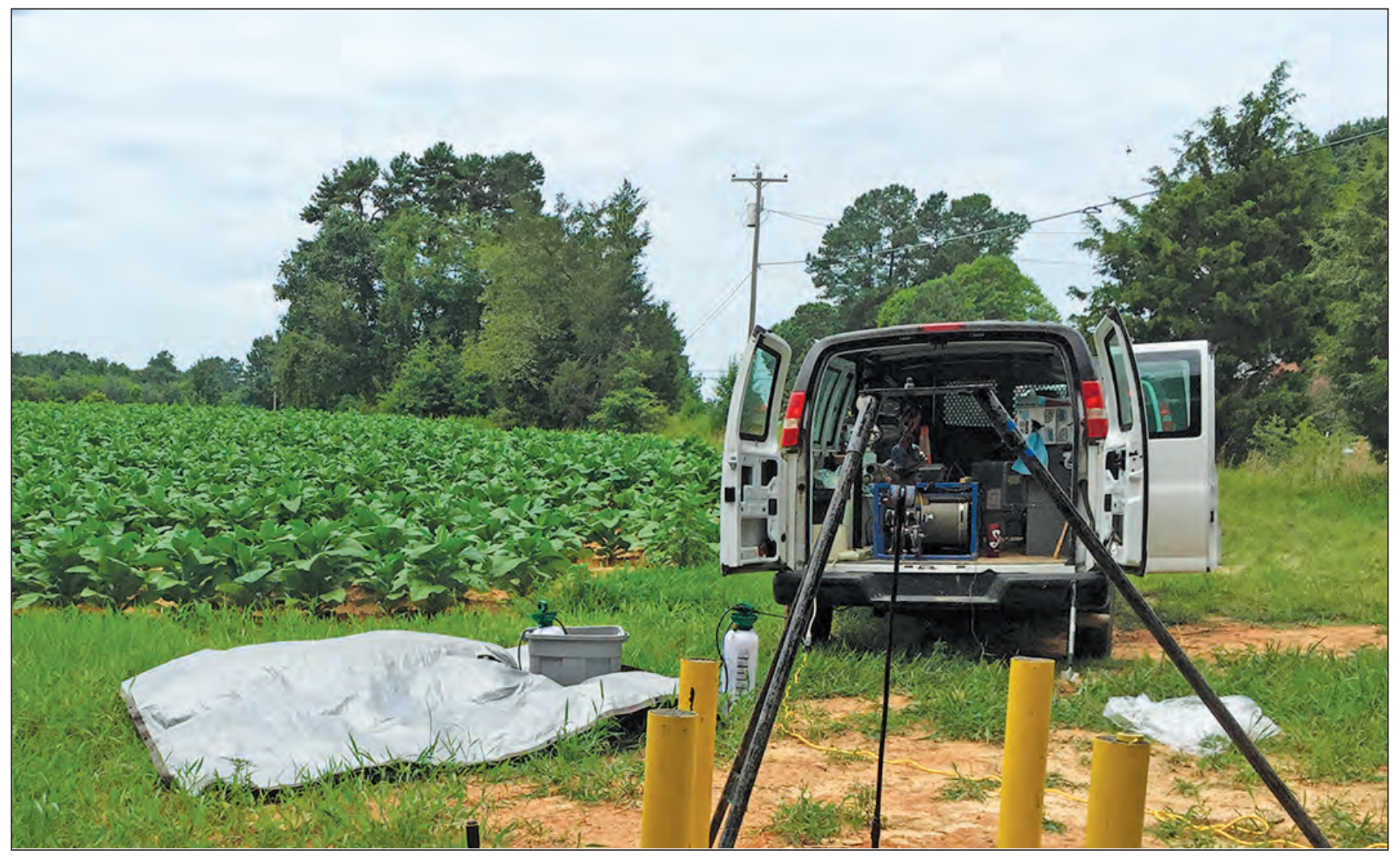

Data Series 1022 
Cover. Borehole geophysical logging setup near monitoring well PS-116 at GMH Electronics site near Roxboro, North Carolina, June 2015. Photograph by Dominick Antolino, USGS. 


\section{Continued Geophysical Logging Near the GMH Electronics National Priorities List Superfund Site Near Roxboro, North Carolina}

By Dominick J. Antolino and Melinda J. Chapman

Prepared in cooperation with the U.S. Environmental Protection Agency

Region 4 Superfund Section

Data Series 1022 


\section{U.S. Department of the Interior SALLY JEWELL, Secretary}

\section{U.S. Geological Survey Suzette M. Kimball, Director}

\section{U.S. Geological Survey, Reston, Virginia: 2017}

For more information on the USGS - the Federal source for science about the Earth, its natural and living resources, natural hazards, and the environment-visit https://www.usgs.gov or call 1-888-ASK-USGS.

For an overview of USGS information products, including maps, imagery, and publications, visit https://store.usgs.gov.

Any use of trade, firm, or product names is for descriptive purposes only and does not imply endorsement by the U.S. Government.

Although this information product, for the most part, is in the public domain, it also may contain copyrighted materials as noted in the text. Permission to reproduce copyrighted items must be secured from the copyright owner.

Suggested citation:

Antolino, D.J., and Chapman, M.J., 2017, Continued geophysical logging near the GMH Electronics National Priorities List Superfund site near Roxboro, North Carolina: U.S. Geological Survey Data Series 1022, 37 p., https://doi.org/ $10.3133 / \mathrm{ds} 1022$.

ISSN 2327-638X (online) 


\section{Contents}

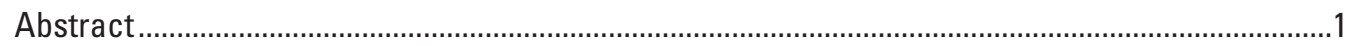

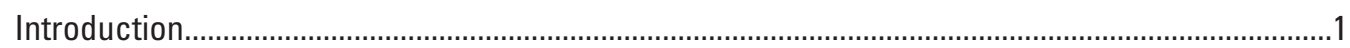

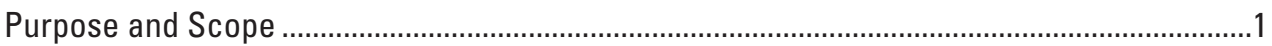

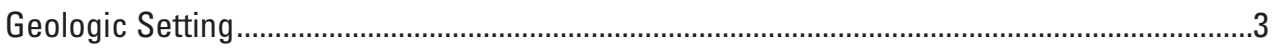

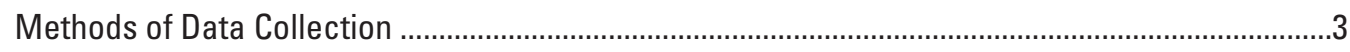

Borehole Geophysical Logging and Imaging Data .....................................................................

Continuous Water-Level Data ....................................................................................................

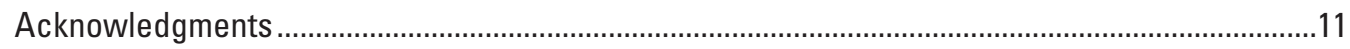

References Cited............................................................................................................................13

Appendix 1. Borehole Geophysical Image Logs Showing Orientations of Subsurface

Structural Features .........................................................................................................15

Appendix 2. Borehole Geophysical Logs Showing Depth of Fracture Zones and

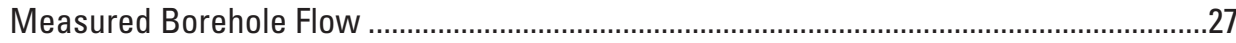

\section{Figures}

1. Maps showing location of the GMH Electronics National Priorities List Superfund site near Roxboro and geologic units within Person County and regional geologic terranes in the North Carolina Piedmont physiographic province .....2

2. Image showing topography near the GMH Electronics National Priorities List Superfund site and new wells logged as part of this continued study, Roxboro, Person County, North Carolina

3. Rose diagram showing strike orientation for all structures measured in the 10 wells logged near the GMH Electronics National Priorities List Superfund site, Roxboro, Person County, North Carolina.

4. Rose diagram showing strike orientation of subsurface foliation measurements from the 10 wells logged near the GMH Electronics National Priorities List Superfund site, Roxboro, Person County, North Carolina....

5. Rose diagram showing dominant orientations of open fractures measured in the 10 wells derived from optical and acoustic televiewer image logs, near the GMH Electronics National Priorities List Superfund site, Roxboro, Person County, North Carolina

6. Image showing well locations and distribution of subsurface structures measured in 10 open borehole wells from optical and acoustic televiewer image logs near the GMH Electronics National Priorities List Superfund site, Roxboro, Person County, North Carolina

7. Borehole geophysical logs from well PS-115 showing fracture zones and upward vertical flow at depth, near the GMH Electronics National Priorities List Superfund site, Roxboro, Person County, North Carolina 
8. Borehole geophysical logs from well PS-118 showing fracture zones an downward vertical flow at depth, near the GMH Electronics National Priorities

List Superfund site, Roxboro, Person County, North Carolina

9. Northwest-to-southeast three-dimensional diagram showing subsurface structures in selected wells, view from North, near the GMH Electronics National Priorities List Superfund site, Roxboro, Person County, North Carolina...........10

10. Southwest-to-northeast three-dimensional diagram showing subsurface structures in selected wells, view from South, near the GMH Electronics National Priorities List Superfund site, Roxboro, Person County, North Carolina.

\section{Tables}

1. Characteristics of the 10 wells logged near the GMH Electronics National Priorities List Superfund site, Roxboro, Person County, North Carolina

2. U.S. Geological Survey FLASH program modeling results for heat-pulse flowmeter logs collected from the 10 wells near the GMH Electronics National Priorities List Superfund site, Roxboro, Person County, North Carolina

3. Period of record for continuously monitored wells near the GMH Electronics National Priorities List Superfund site in Roxboro, Person County, North Carolina, 2012-13 


\section{Conversion Factors}

U.S. customary units to International System of Units

\begin{tabular}{lcl}
\hline \multicolumn{1}{c}{ Multiply } & By & \multicolumn{1}{c}{ To obtain } \\
\hline inch (in.) & Length & \\
inch (in.) & 2.54 & centimeter $(\mathrm{cm})$ \\
foot (ft) & 25.4 & millimeter $(\mathrm{mm})$ \\
mile (mi) & 0.3048 & meter $(\mathrm{m})$ \\
\hline & 1.609 & kilometer $(\mathrm{km})$ \\
\hline gallon per minute $(\mathrm{gal} / \mathrm{min})$ & Flow rate & \\
\hline & 0.06309 & liter per second $(\mathrm{L} / \mathrm{s})$ \\
\hline foot squared per day (ft $/ \mathrm{d})$ & Transmissivity & \\
\hline
\end{tabular}

Temperature in degrees Fahrenheit $\left({ }^{\circ} \mathrm{F}\right)$ may be converted to degrees Celsius $\left({ }^{\circ} \mathrm{C}\right)$ as follows:

$$
{ }^{\circ} \mathrm{C}=\left({ }^{\circ} \mathrm{F}-32\right) / 1.8
$$

\section{Datums}

Vertical coordinate information is referenced to the North American Vertical Datum of 1988 (NAVD 88).

Horizontal coordinate information is referenced to the North American Datum of 1983 (NAD 83).

Altitude, as used in this report, refers to distance above the vertical datum.

\section{Supplemental Information}

Transmissivity: The standard unit for transmissivity is cubic foot per day per square foot times foot of aquifer thickness $\left(\left[\mathrm{ft}^{3} / \mathrm{d}\right] / \mathrm{ft}^{2}\right) \mathrm{ft}$. In this report, the mathematically reduced form, foot squared per day $\left(\mathrm{ft}^{2} / \mathrm{d}\right)$, is used for convenience.

Specific conductance is given in microsiemens per centimeter at 25 degrees Celsius $(\mu \mathrm{S} / \mathrm{cm}$ at $\left.25^{\circ} \mathrm{C}\right)$.

Natural gamma $(\gamma)$ radiation is given in American Petroleum Institute Units (APIU).

Resistivity is given in ohm meters $(\Omega-\mathrm{m})$, and resistance is given in ohms $(\Omega)$.

Some geologic ages are given in millions of years ago (Ma).

\section{Abbreviations}
ATV acoustic televiewer
EPA U.S. Environmental Protection Agency
NPL National Priorities List
OTV optical televiewer
USGS U.S. Geological Survey 



\title{
Continued Geophysical Logging Near the GMH Electronics National Priorities List Superfund Site Near Roxboro, North Carolina
}

\author{
By Dominick J. Antolino and Melinda J. Chapman
}

\begin{abstract}
The U.S. Geological Survey South Atlantic Water Science Center collected borehole geophysical logs and images and continuous water-level data near the GMH Electronics National Priorities List Superfund site near Roxboro, North Carolina, during December 2012 through July 2015. Previous work by the U.S. Geological Survey South Atlantic Water Science Center at the site involved the collection of borehole geophysical log data in 15 wells, in addition to surface geologic mapping and passive diffusion bag sampling. In a continued effort to assist the U.S. Environmental Protection Agency in developing a conceptual groundwater model to assess current contaminant distribution and future migration of contaminants, more than 900 subsurface features (primarily fracture orientations) in 10 open borehole wells were delineated and continuous water-level data information from 14 monitoring wells within close proximity of the initially drilled boreholes was collected to observe any induced water-level fluctuations during drilling operations.
\end{abstract}

\section{Introduction}

The GMH Electronics National Priorities List (NPL) Superfund site is near the intersection of Halifax and Virgilina Roads, about 1 mile (mi) northeast of Roxboro in Person County, North Carolina (fig. 1). Regionally, the study area is in the Piedmont physiographic province in North Carolina, which is within the metamorphosed intrusive rocks of the Carolina Slate Belt within the Carolina Terrane (North Carolina Geological Survey, 1985).

As elsewhere in the Piedmont physiographic province, the groundwater system within the study area is complex because of multiple periods of structural deformation, metamorphism, and igneous intrusion. The aquifer largely consists of a three-part system of shallow weathered regolith, an intermediate transition zone, and deeper fractured bedrock. The shallow weathered regolith is the primary storage reservoir and is the source of recharge to the deeper bedrock fractures (Heath, 1980, 1983, 1984, 1994). In areas where the intermediate transition zone exists between the shallow weathered regolith and deeper fractured bedrock, permeability is enhanced near the top of the bedrock with increased fracture density (Chapman and others, 2005; Huffman and others, 2006; McSwain and others, 2008, 2013; Pippin and others, 2008). Most of the community and private groundwater supply wells in the area are completed within the bedrock section of the groundwater system, where water moves through secondary openings in the form of fractures and other complex discontinuities (such as differential weathering along lithologic contacts). These secondary openings are the primary source of permeability in the bedrock; thus, the mapping of fractures and other geologic features is critical to the understanding of groundwater transport to wells and the delineation of pathways of contaminant transport.

In June 2010, the U.S. Geological Survey (USGS) received a request to assist the U.S. Environmental Protection Agency (EPA) Region 4 Superfund Section in the development of a conceptual groundwater model in the area of the GMH Electronics NPL Superfund site near Roxboro, N.C. (formerly the Halifax Road DCE site) through an interagency agreement. The USGS's effort included the application of borehole geophysical tools and methods used to delineate and characterize fracture zones within 15 wells in the regolithfractured bedrock aquifer and assistance toward the development of a conceptual model of flow in the bedrock part of the groundwater system that can be used to evaluate contaminant concentrations and future migration. In order to further characterize the aquifer system for groundwater flow, subsequent field efforts were completed at the study site in December 2012, January 2013, and July 2015 using similar geophysical techniques within 10 newly drilled boreholes by the EPA for this study.

\section{Purpose and Scope}

The purpose of this report is to present geophysical logging and information on wells used to collect groundwaterlevel data near the GMH Electronics NPL Superfund site near Roxboro, N.C. (fig. 1). Borehole geophysical logs were collected from 10 open borehole wells (fig. 2) completed within the bedrock part of the aquifer and used to delineate and characterize fracture zones. Water-level data were also 


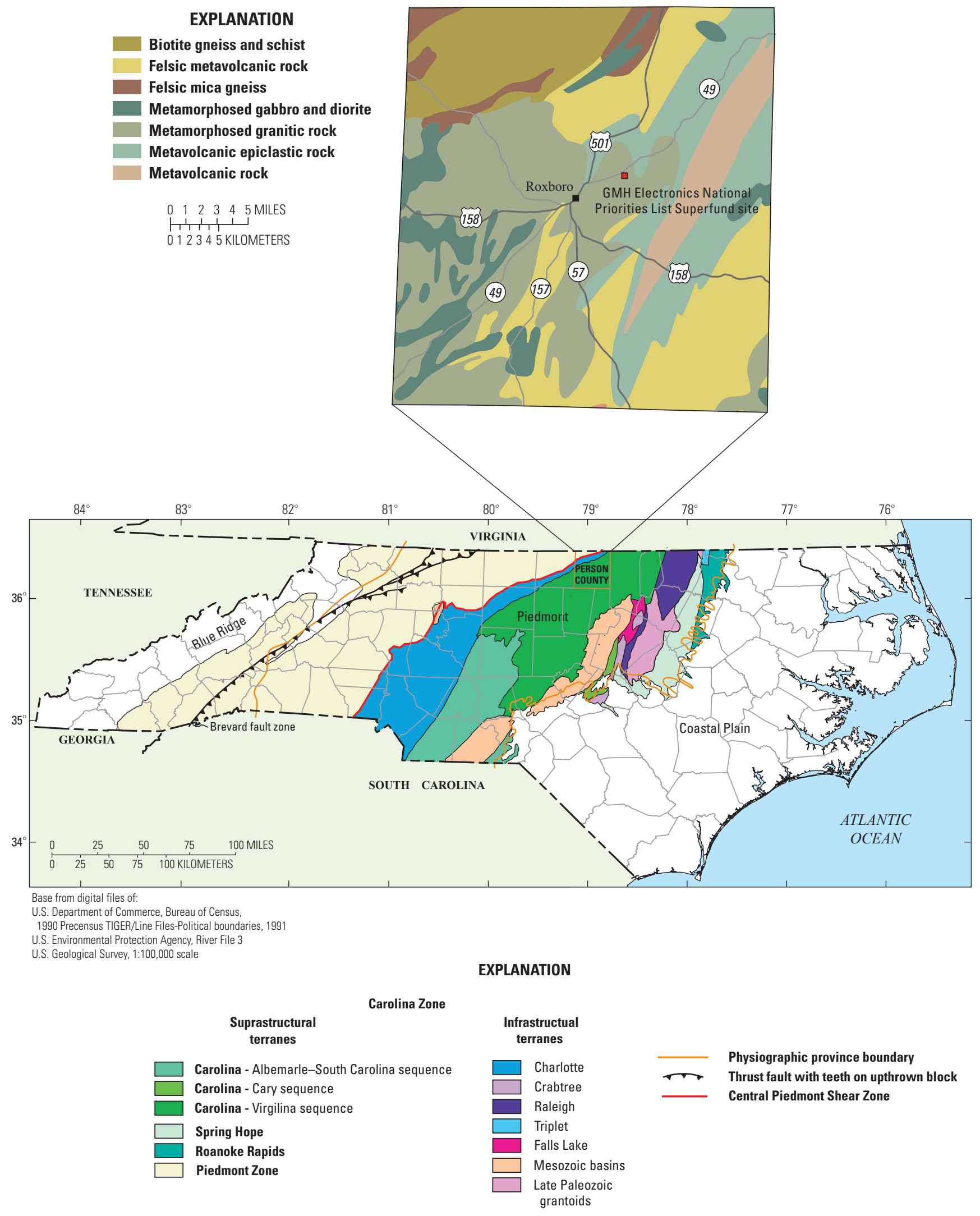

Figure 1. Location of the GMH Electronics National Priorities List Superfund site near Roxboro and geologic units within Person County and regional geologic terranes in the North Carolina Piedmont physiographic province (modified from North Carolina Geological Survey, 1985; Hibbard and others, 2002). 
collected in 14 monitoring wells using self-logging pressure transducers before, during, and after drilling the initial boreholes for this study (PS-108, PS-109, PS-111, and PS-112) in order to capture any induced water-level fluctuations.

\section{Geologic Setting}

The GMH Electronics NPL Superfund site is within the Roxboro metagranite (metamorphosed granitic rock, fig. 1), which is a complex igneous body that intruded older volcanic and volcanoclastic rocks of the Carolina Terrane (Hibbard and others, 2002) about 575 million years ago (Ma) during the Ediacaran Period (Neoproterozoic Era). The older volcanic and volcaniclastic rocks of the Carolina Terrane (Hibbard and others, 2002) were deposited at least 25 million years earlier because they were metamorphosed, faulted, and folded by the 600 Ma Virgilina deformation event. Virgilina sequence rocks are a few miles to the north, east, and west of the GMH Electronics NPL Superfund site. Continued erosion and unroofing with time has resulted in the present exposure of metamorphosed granite and metamorphosed volcanic rocks at land surface within the region. The Roxboro metagranite is predominately granitic in composition, although locally contains phases that are more representative of a granodiorite (Briggs and others, 1978).

Recent mapping within the southern parts of the Roxboro pluton indicate that it has been intruded by diorite to gabbro dikes that trend northeast-southwest (Phil Bradley, North Carolina Geological Survey, written commun., 2010). Prior field observations made near the GMH Electronics NPL Superfund site (Chapman and others, 2013) indicate that these dikes seem to have experienced the same metamorphism as the granite and are interpreted to have intruded the granite shortly after its formation in the Neoproterozoic Era. These dikes form discontinuities in the granite that may serve as permeable pathways in the subsurface.

\section{Methods of Data Collection}

Methods similar to those described in Chapman and others (2013) were used to continue to characterize the subsurface features in the fractured bedrock and overlying regolith near the GMH Electronics NPL Superfund site (figs. 1, 2; table 1). Borehole geophysical logs were collected in 10 wells near the GMH Electronics NPL Superfund site from December 2012 to July 2015 (table 1; fig. 2). Logs collected from each of the 10 wells included caliper, electrical resistivity, natural gamma, fluid temperature and resistivity, heat-pulse flowmeter (ambient and stressed), optical televiewer (OTV), and acoustic televiewer (ATV) data (see appendix 1 and 2 figures). After geophysical logging was completed at each borehole, the tools were each decontaminated with deionized water and nonphosphate soap. Rinse samples were collected after the tools were decontaminated and were analyzed for volatile organic compounds to ensure that no contaminants were transferred from well to well as part of the geophysical logging process. These rinse samples were collected before geophysical logging began, between the logging of selected wells, and after the completion of the logging field effort. Analytical data from the borehole-logging-tool rinse samples are available through the National Water Information System Web site at http://dx.doi.org/10.5066/F7P55KJN.

Geophysical logs were used to characterize subsurface bedrock structures by primary lithology, fracture characteristics, foliation (if present), secondary lithologies, and lithologic contacts. Fracture zone characteristics delineated in the 10 wells logged as part of this study include depth, strike orientation, dip angle, measured flow, and modeled hydraulic characteristics. Fracture zones were delineated for each well using all the available borehole logs, including visual delineation from OTV images, increases in caliper-log diameter, electrical resistivity decreases (below the water level), and inflections or slope changes in the fluid temperature and specific conductance logs.

Continuous, oriented digital color images of the granite bedrock in the subsurface were recorded from OTV image logs. These logs are oriented using a magnetometer built into the borehole tool; thus, the orientations of structural features can be determined using adjustments for local magnetic declination. Images of the granite were used to interpret texture and delineate secondary compositional changes, such as the presence of mafic lenses. Where the water in the well was not clear enough for interpretation, an ATV tool was used to image the fractures and determine orientations.

Orientations of subsurface fractures (open and sealed), foliation, and lithologic contacts were determined from the OTV and ATV image logs using WellCad software (Advanced Logic Technology, 2010). Fracture orientations were determined from OTV and ATV images, which were corrected for magnetic declination (National Oceanic and Atmospheric Administration, 2015) and borehole deviation. Orientations interpreted from the OTV image logs were adjusted for a local magnetic declination of $9^{\circ}$ west and for measured borehole deviation. WellCad (Advanced Logic Technology, 2010) was used to produce rose diagrams to display delineated fracture orientations. Subsurface structural orientations were imported into Rockworks software (Rockware, Inc., 2010) for three-dimensional display of fracture planes at depth.

Vertical flow was measured at selected depths above and below fractures within the boreholes using a heat-pulse flowmeter. Fracture zones were selected for heat-pulse flowmeter logging based on interpretations from caliper, electrical resistivity, fluid (temperature and specific conductance) logs, and OTV/ATV image logs and interpretations. Positive heat-pulse flow measurements indicated upflow within the borehole, whereas negative heat-pulse flow measurements indicated downflow. Results from ambient (natural flow) and stressed (pumped flow) measurements from heat-pulse flowmeter logs were modeled for aquifer properties (hydraulic 


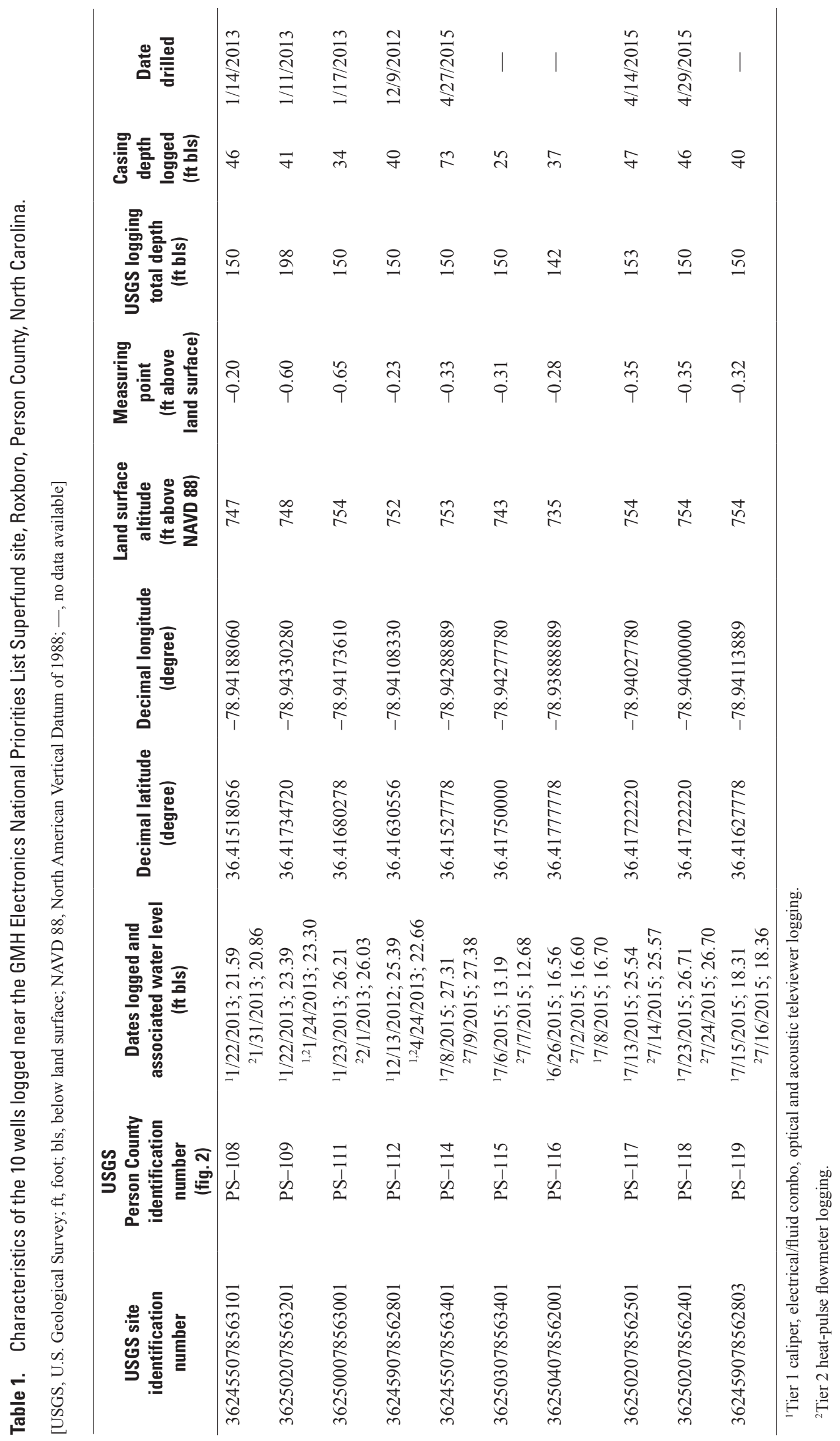




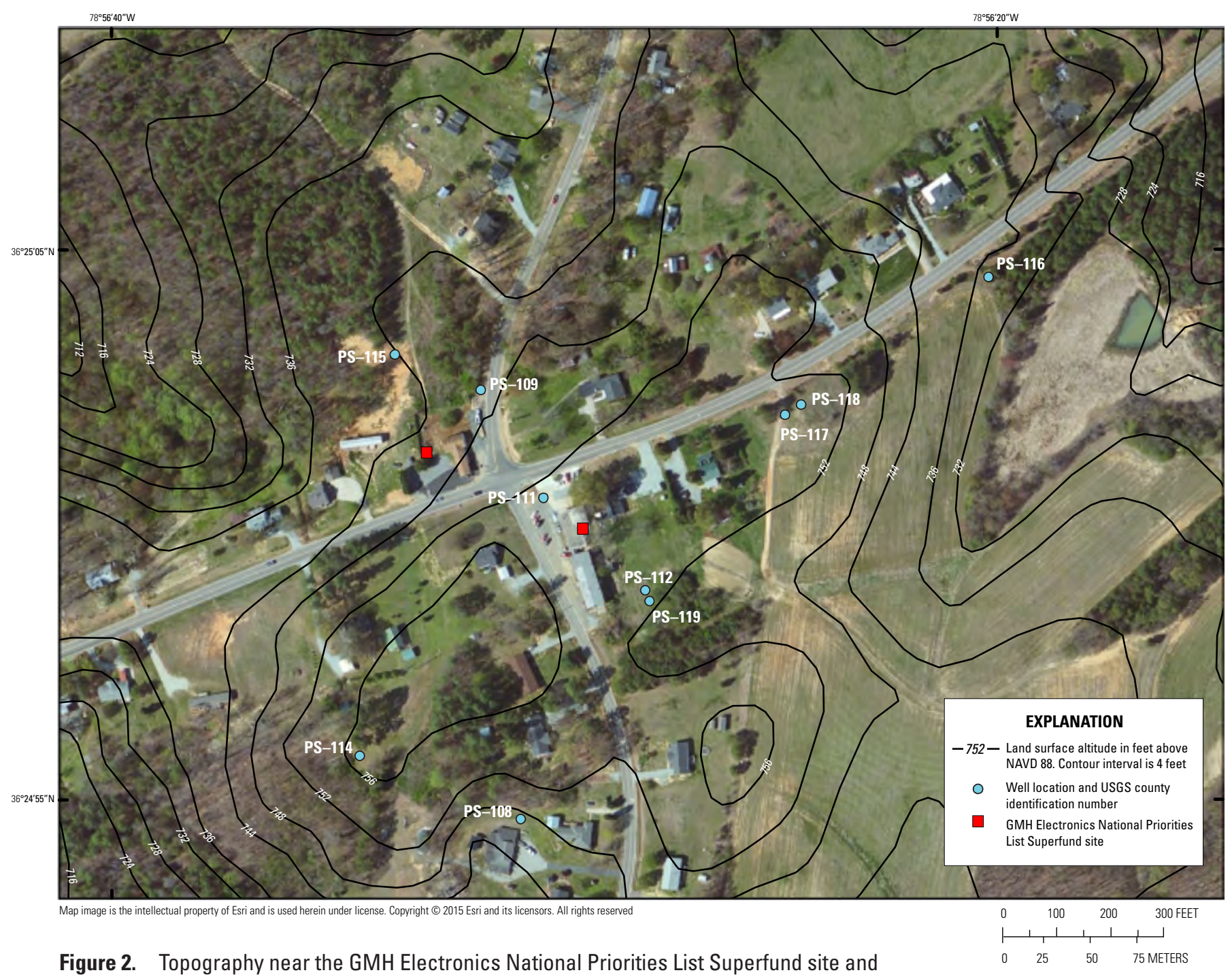

new wells logged as part of this continued study, Roxboro, Person County, North Carolina.

head differences, transmissivity, and radius of influence) using the published USGS FLASH program (Day-Lewis and others, 2011; http://water.usgs.gov/ogw/flash/). FLASH is an Excel $^{\circledR}$-based utility for the analysis of vertical flow logs and is based on an analytical solution for steady-state, multilayer radial flow to a borehole. The program can estimate aquifer properties of multiple discrete intervals (fractures or layers) either manually through a graphical-user interface or with an automated model calibration.

\section{Borehole Geophysical Logging and Imaging Data}

The 10 wells used for borehole geophysical logging were within a 1/4-mi radius of the GMH Electronics NPL
Superfund site (fig. 2; table 1). Well depths ranged from about 140 to 200 feet (ft) below land surface. The casing depths compiled in table 1 indicate the inferred regolith thickness ranges from about 25 to $73 \mathrm{ft}$ below land surface. Water levels measured in all 10 wells during December 2012 through July 2015 ranged from 12.68 to $27.38 \mathrm{ft}$ below land surface.

The logs collected from the caliper, OTV, and ATV, along with the interpreted subsurface structure measurements within the granite bedrock and secondary textural features, are provided in appendix 1. Structures were characterized as either primary (open) fractures, secondary (partially open or weathered) fractures, sealed fractures (often filled with secondary minerals), foliation, or lithologic contacts. More than 900 subsurface structural measurements (orientations) were interpreted from OTV and ATV images collected (see fig. 2 for well locations). 


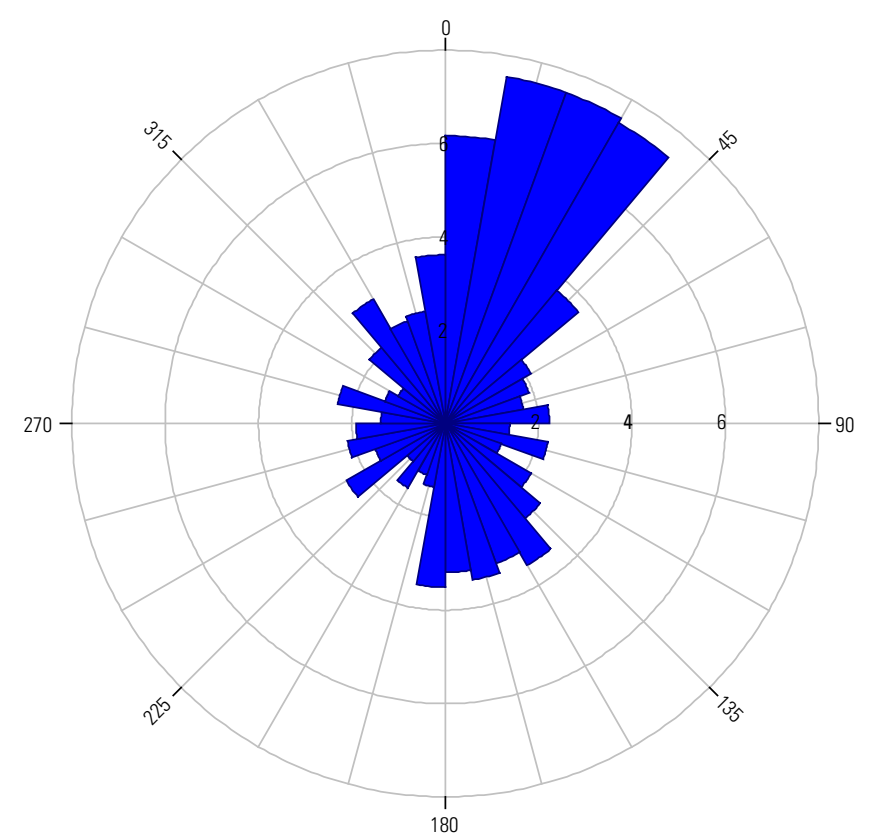

Figure 3. Strike orientation for all structures measured in the 10 wells logged near the GMH Electronics National Priorities List Superfund site, Roxboro, Person County, North Carolina. Length of petal corresponds to percentage of the total number of measurements.

Strike orientations for all structures measured in the 10 wells logged as part of this study are presented in figure 3 . The subsurface structure dataset indicates that the most common strike orientations are $11^{\circ}-30^{\circ}$ and $31^{\circ}-40^{\circ}$. Subsurface structural orientations for individual wells are provided in Antolino and Chapman (2016). The subsurface foliation measurements had a dominant orientation of $21^{\circ}-30^{\circ}$ (fig. 4), which parallels that of the surface foliation data collected from outcrop measurements during the previous field effort (Chapman and others, 2013). The dominant strike orientations for the open fractures were $161^{\circ}-170^{\circ}$ (fig. 5); the average dip angle for the open fractures was $29^{\circ}$. The primary open fractures were between 615 and $722 \mathrm{ft}$ in altitude (31 to $128 \mathrm{ft}$ below land surface).

The areal distribution of structures (excluding foliation) measured in the 10 wells logged is shown in figure 6 . The most common dominant open fracture orientation within the wells measured was $161^{\circ}-170^{\circ}$, which was observed in 6 of the 10 wells. Other dominant orientations observed in the 10 wells were $21^{\circ}-30^{\circ}, 0^{\circ}-10^{\circ}$, and $140^{\circ}-150^{\circ}$. The $21^{\circ}-30^{\circ}$ structure orientation parallels that of surface foliation and joints seen previously at the study site (Chapman and others, 2013).

Sets of borehole geophysical logs in which fracture zones were delineated and flow was measured and modeled for each of the 10 wells are provided in appendix 2. Ambient vertical groundwater flow was modeled by FLASH in 4 of the 10 wells-PS-111, PS-115, PS-116, and PS-118. For ambient measurements, measured flow often was near zero

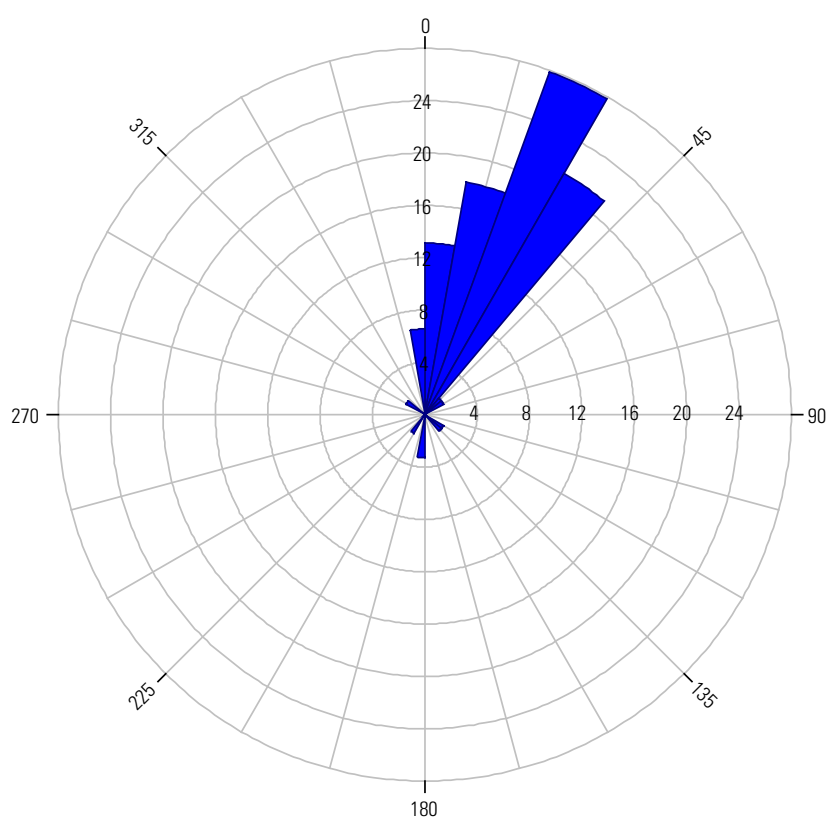

Figure 4. Strike orientation of subsurface foliation measurements from the 10 wells logged near the $\mathrm{GMH}$ Electronics National Priorities List Superfund site, Roxboro, Person County, North Carolina. Length of petal corresponds to percentage of the total number of measurements.

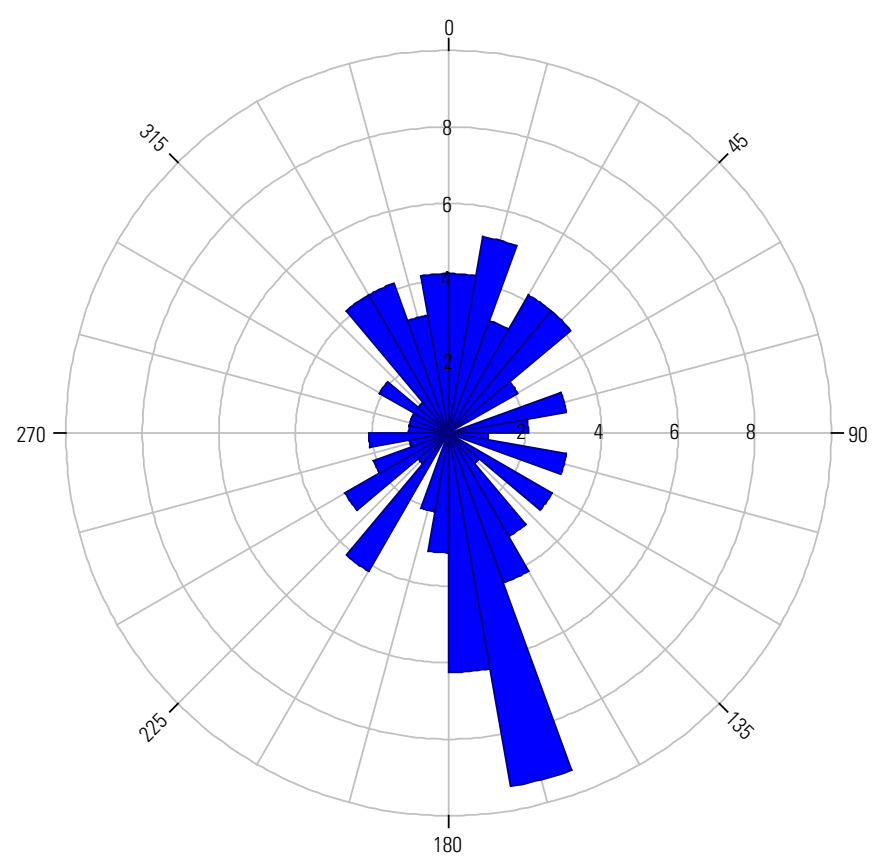

Figure 5. Dominant orientations of open fractures measured in the 10 wells derived from optical and acoustic televiewer image logs, near the GMH Electronics National Priorities List Superfund site, Roxboro, Person County, North Carolina. Length of petal corresponds to percentage of the total number of measurements. 


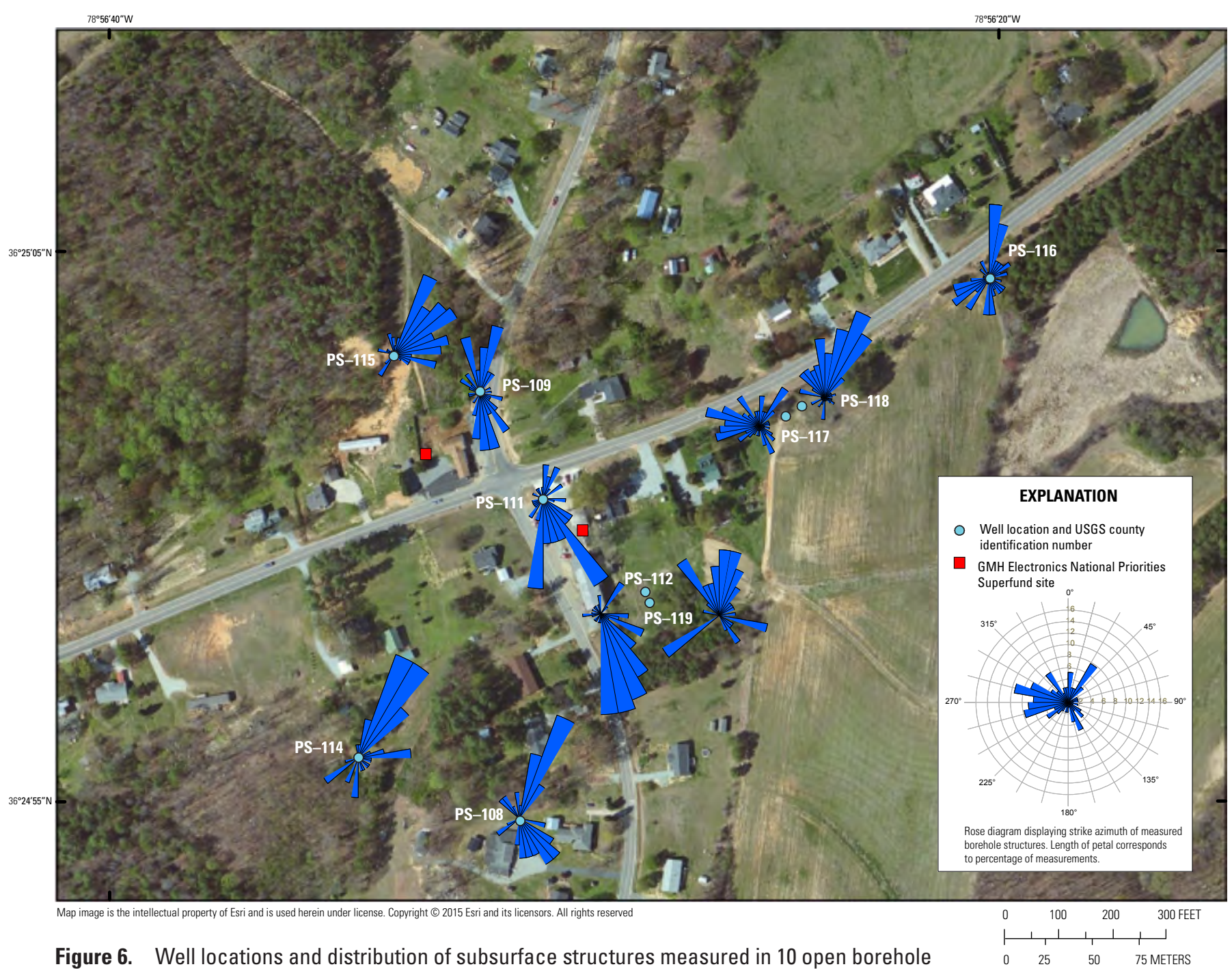

wells from optical and acoustic televiewer image logs near the GMH Electronics National Priorities List Superfund site, Roxboro, Person County, North Carolina.

or "no flow." Values of 0.01 to 0.03 gallons per minute (gal/min) are near the lower resolution of the measuring tool and, thus, may be considered "noise."

In well PS-115 (fig. 7), inflow is modeled at the 81-ft fracture zone, outflow is modeled near the $32-\mathrm{ft}$ fracture zone, and flow is upward between the two zones. In well PS-118 (fig. 8), inflow is at the 54-ft fracture zone, outflow is near the $71-\mathrm{ft}$ fracture zone, and flow is downward between the two zones. Flow direction arrows in figures 7 and 8 reflect modeled (simplified) flow. For example, flow may have been measured at several fractures; however, FLASH modeling results typically portray only dominant fracture zones, thereby reducing the number of fractures contributing flow. A larger number of contributing fracture zones were initially modeled using FLASH; however, some fracture zones were removed from the model because erroneous hydraulic heads were simulated (for example, 1,000 ft higher head compared to the zone above).
Transmissivity estimates for the 10 wells ranged from 1.1 to 45 feet squared per day ( $\left.\mathrm{ft}^{2} / \mathrm{d}\right)$, and estimates of the radius of influence ranged from 6 to $147 \mathrm{ft}$ (table 2). Initial estimates of transmissivity were made using empirical relations of specific capacity and transmissivity in fractured metamorphic and crystalline rocks (Srivastav and others, 2007) and were determined to be within an order of magnitude of the results from the FLASH models. The depth of fractures where flow was modeled ranged from 32 to $134 \mathrm{ft}$ below land surface.

The three-dimensional diagrams of borehole structures shown in figures 9 and 10 indicate potential interconnectivity of fracture zones between wells. Fractures having similar dip azimuths and angles are recognized as parallel fracture images. The distribution of subsurface fractures and their associated three-dimensional orientations can potentially control contaminant migration, depending on the location of source areas and hydraulic head distributions between fracture zones. 


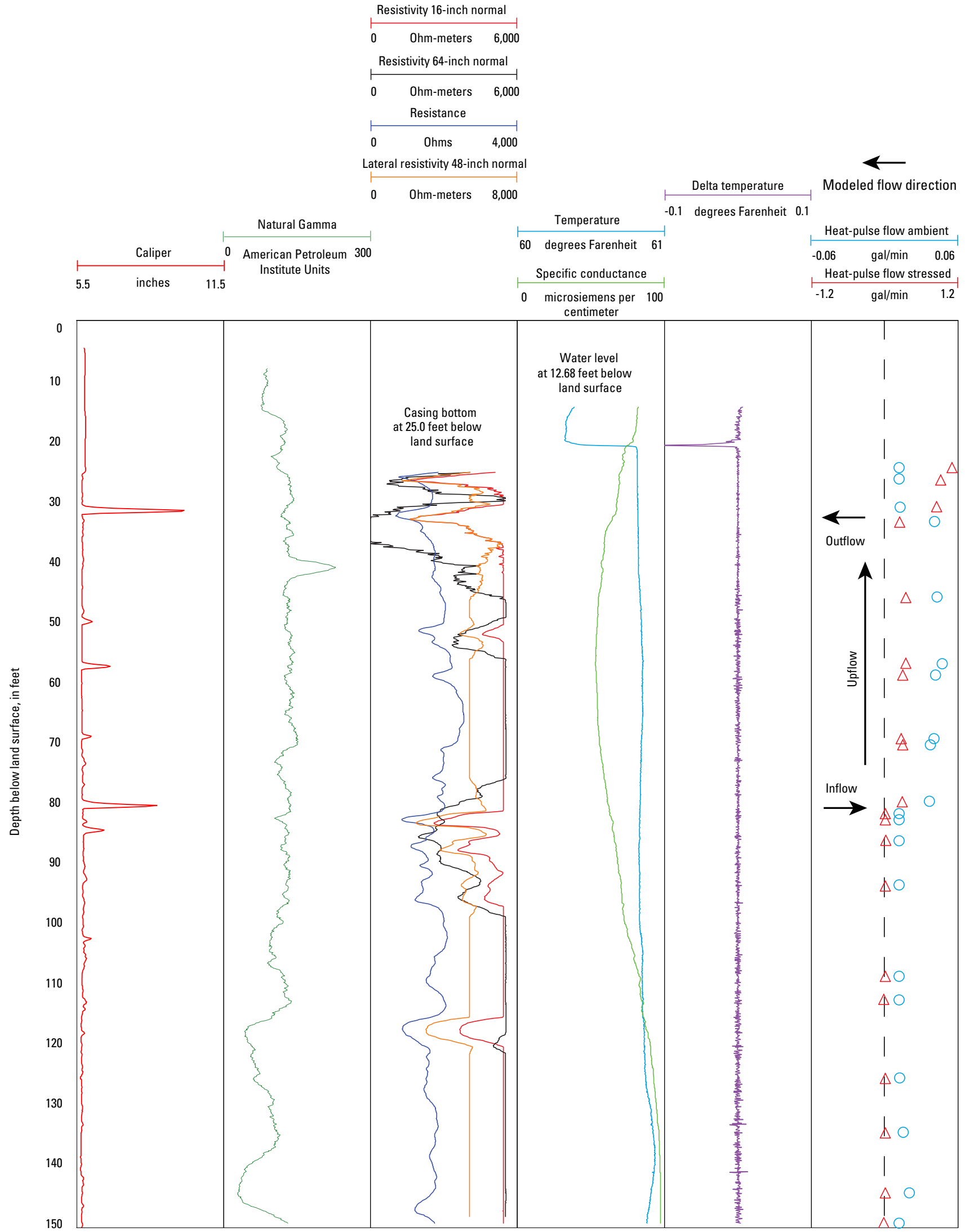

Figure 7. Borehole geophysical logs from well PS-115 showing fracture zones and upward vertical flow at depth, near the GMH Electronics National Priorities List Superfund site, Roxboro, Person County, North Carolina. 


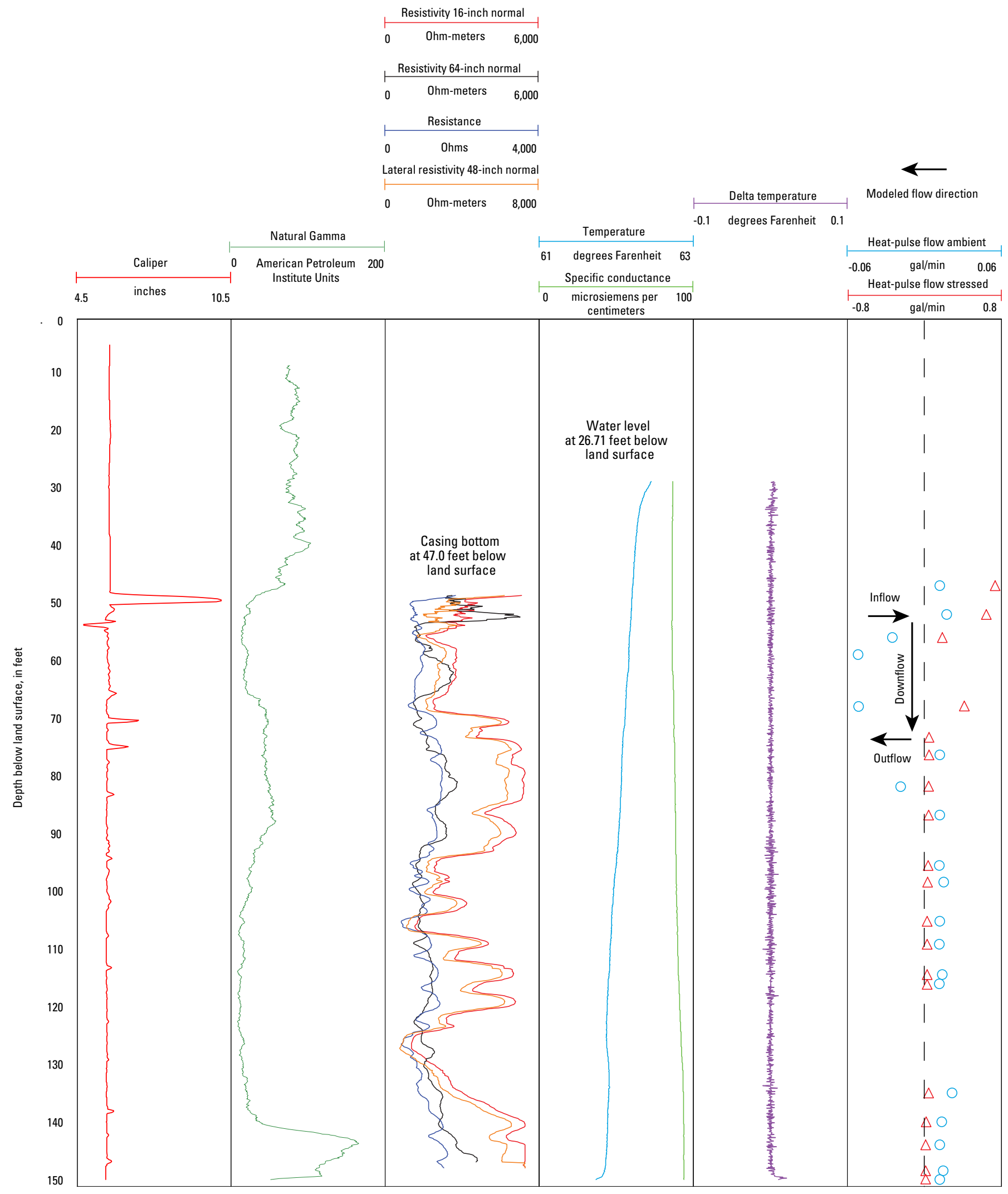

Figure 8. Borehole geophysical logs from well PS-118 showing fracture zones and downward vertical flow at depth, near the GMH Electronics National Priorities List Superfund site, Roxboro, Person County, North Carolina. 
Table 2. U.S. Geological Survey FLASH program modeling results for heat-pulse flowmeter logs collected from the 10 wells near the GMH Electronics National Priorities List Superfund site, Roxboro, Person County, North Carolina.

\begin{tabular}{ccc} 
[USGS, U.S. Geological Survey; $\mathrm{ft}^{2} / \mathrm{d}$, foot squared per day; ft, foot] \\
\hline $\begin{array}{c}\text { USGS Person County } \\
\text { identification number (fig. 2) }\end{array}$ & $\begin{array}{c}\text { Estimated transmissivity } \\
\left.\text { (ft }{ }^{2} / \mathbf{d}\right)\end{array}$ & $\begin{array}{c}\text { Radius of influence } \\
\text { (ft) }\end{array}$ \\
\hline PS-108 & 20 & 147 \\
PS-109 & 1.1 & 6 \\
PS-111 & 28 & 12 \\
PS-112 & 45 & 12 \\
PS-114 & 4.6 & 100 \\
PS-115 & 17 & 12 \\
PS-116 & 11 & 9 \\
PS-117 & 17 & 18 \\
PS-118 & 20 & 6 \\
PS-119 & 28 & 7 \\
\hline
\end{tabular}

\section{Northwest}

PS-115

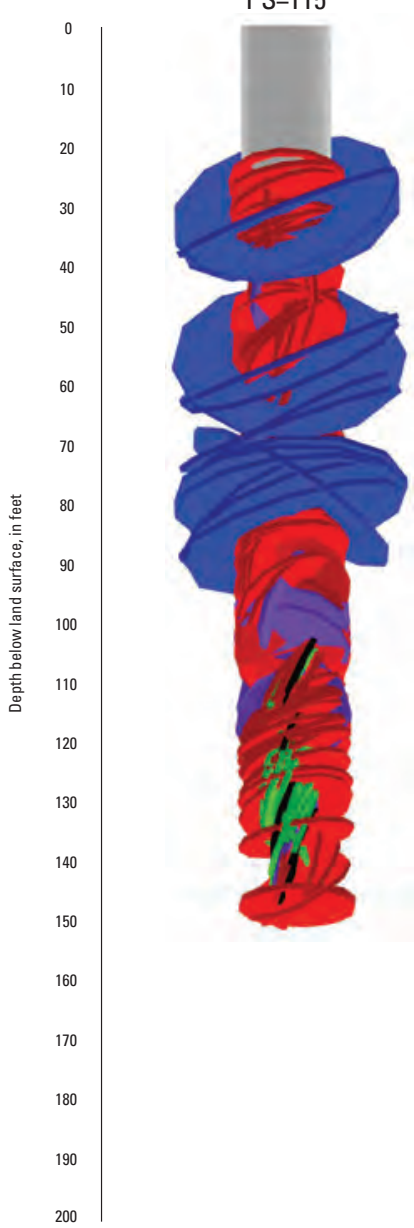

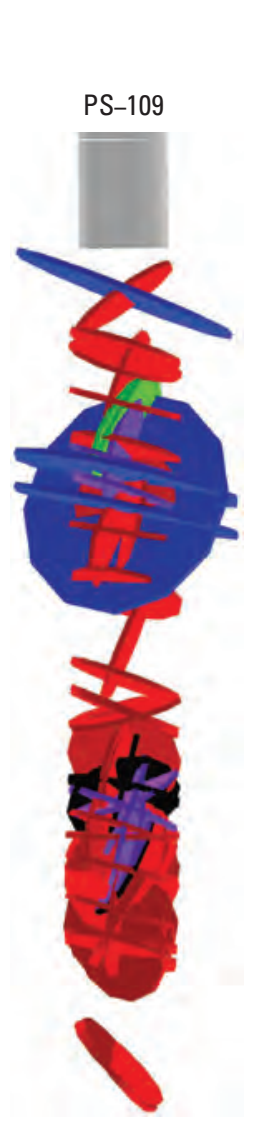

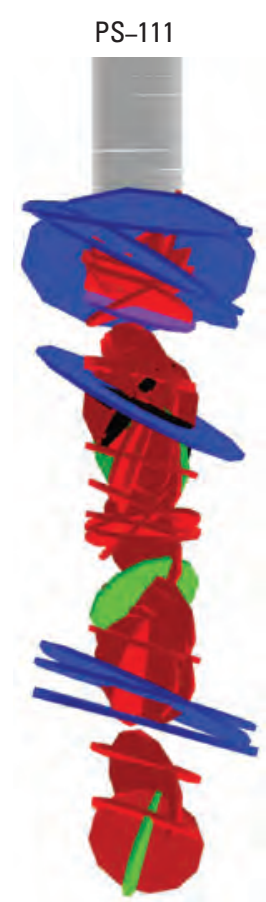

PS-112 PS-119

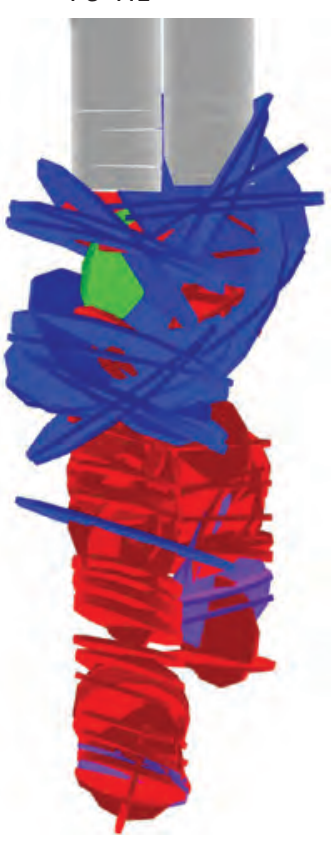

\section{EXPLANATION}

- Primary fracture

- Secondary fracture

Foliation

Sealed fracture

- Lithologic contact

Figure 9. Northwest-to-southeast three-dimensional diagram showing subsurface structures in selected wells, view from North, near the GMH Electronics National Priorities List Superfund site, Roxboro, Person County, North Carolina. 


\section{Southwest}

Northeast
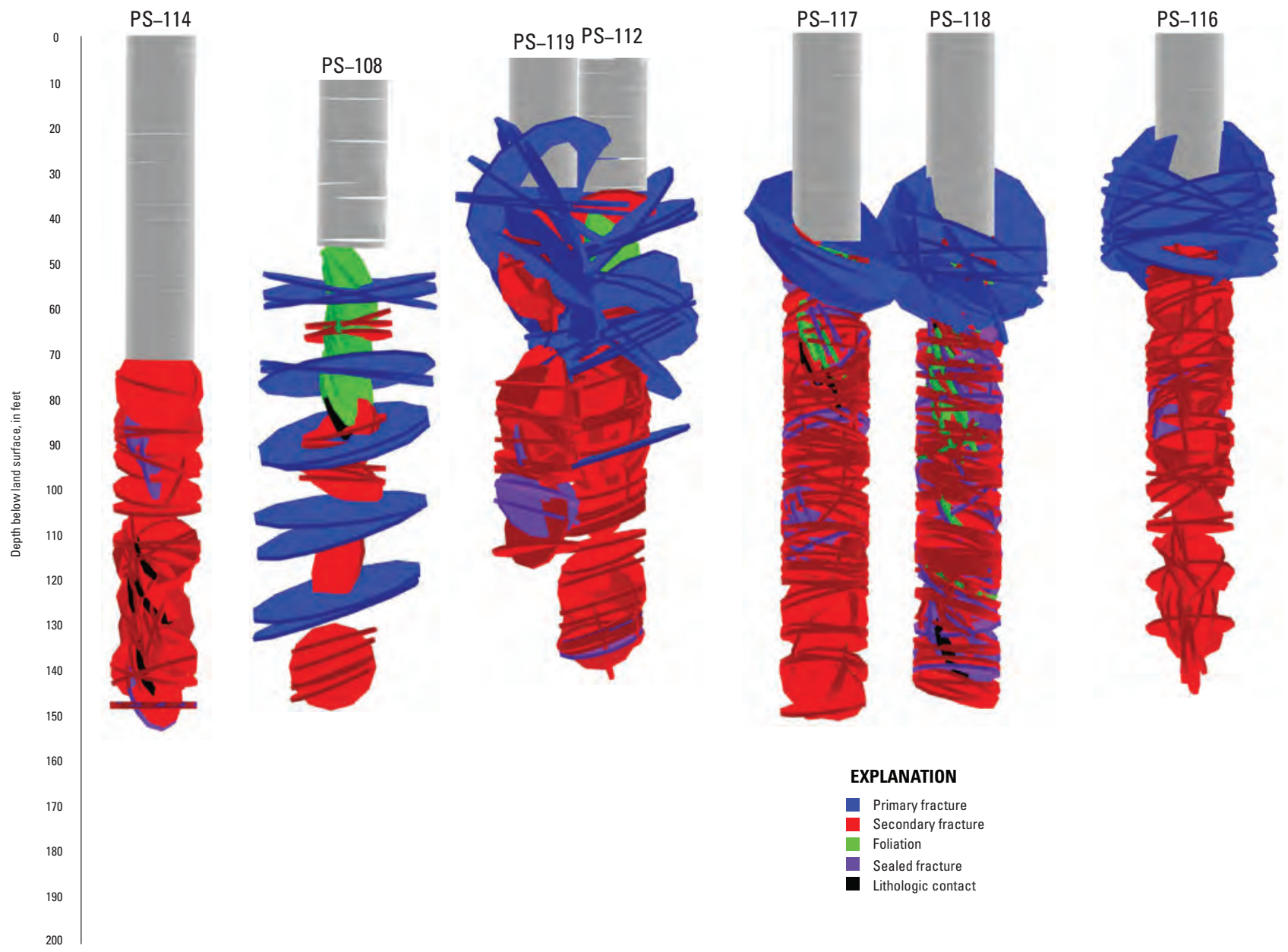

Figure 10. Southwest-to-northeast three-dimensional diagram showing subsurface structures in selected wells, view from South, near the GMH Electronics National Priorities List Superfund site, Roxboro, Person County, North Carolina.

\section{Continuous Water-Level Data}

Continuous groundwater-level measurements were recorded in 14 wells in the study area to monitor any fluctuations before, during, and after drilling operations of the first 4 of the 10 newly drilled bedrock wells PS-108, PS-109, PS-111, and PS-112 (fig. 2). The water-level data were collected using self-logging pressure transducers at 1-minute and 15-minute intervals for those monitoring wells closest to the borehole being drilled. The period of record for each monitoring well and the duration of drilling operations at each of the first four newly drilled boreholes is provided in table 3 . Water-level change measured in monitoring wells during the well drilling activities ranged from 0.5 to more than $23 \mathrm{ft}$. Such water-level change coincident with drilling activities may indicate fracture connectivity, though such discussion goes beyond the scope of this report. Water-level data are available through the National Water Information System Web site at http://dx.doi.org/10.5066/F7P55KJN.

\section{Acknowledgments}

The authors would like to thank Kristen McSwain, Scott Caldwell, and Erik Staub of the U.S. Geological Survey (USGS) South Atlantic Water Science Center for their assistance in the collection of geophysical logs. Appreciation is also extended to USGS colleague reviewers Debbie Gordon and Eve Kuniansky. 
Table 3. Period of record for continuously monitored wells near the GMH Electronics National Priorities List Superfund site in Roxboro, Person County, North Carolina, 2012-13.

[USGS, U.S. Geological Survey; ft, foot; bls, below land surface; NAVD 88, North American Vertical Datum of 1988]

\begin{tabular}{|c|c|c|c|c|c|}
\hline $\begin{array}{c}\text { USGS } \\
\text { Person County } \\
\text { identification } \\
\text { number (fig. 2) }\end{array}$ & $\begin{array}{c}\text { USGS site } \\
\text { identification number }\end{array}$ & Period of record & $\begin{array}{l}\text { Well depth } \\
\text { (ft bls) }\end{array}$ & $\begin{array}{l}\text { Depth to bottom } \\
\text { of casing } \\
\text { (ft bls) }\end{array}$ & $\begin{array}{c}\text { Land-surface } \\
\text { altitude } \\
\text { (feet above } \\
\text { NAVD 88) }\end{array}$ \\
\hline PS-093 & 362453078562701 & $1 / 5 / 2013-1 / 13 / 2013$ & 142 & 42.5 & 750 \\
\hline PS-094 & 362458078563001 & $11 / 28 / 2012-3 / 26 / 2013$ & 124 & 42 & 758 \\
\hline PS-096 & 362515078562701 & $1 / 23 / 2013-5 / 8 / 2013$ & 72 & 62 & 728 \\
\hline PS-097 & 362500078563501 & $11 / 28 / 2012-3 / 26-2013$ & 143 & 52.5 & 740 \\
\hline PS-098 & 362508078562801 & $11 / 27 / 2012-5 / 8 / 2013$ & 62 & 33 & 746 \\
\hline PS-099 & 362458078562601 & $11 / 29 / 2012-5 / 8 / 2013$ & 302 & 64 & 752 \\
\hline PS-100 & 362456078562801 & $11 / 28 / 2012-3 / 26 / 2013$ & 144 & 37.5 & 754 \\
\hline PS-101 & 362454078562901 & $1 / 5 / 2013-5 / 8 / 2013$ & 202 & 55 & 748 \\
\hline PS-102 & 362505078562901 & $12 / 1 / 2012-5 / 8 / 2013$ & 122 & 58 & 748 \\
\hline PS-103 & 362504078562301 & $11 / 28 / 2012-5 / 8 / 2013$ & 167 & 81 & 750 \\
\hline PS-104 & 362505078562301 & $11 / 3 / 2012-5 / 8 / 2013$ & 81 & 65 & 749 \\
\hline PS-105 & 362457078562901 & $11 / 28 / 2012-5 / 8 / 2013$ & 161 & 49 & 754 \\
\hline PS-106 & 362501078562601 & $11 / 28 / 2012-5 / 8 / 2013$ & 127 & 35 & 754 \\
\hline PS-107 & 362501078562701 & $12 / 9 / 2012-5 / 8 / 2013$ & 118 & 52 & 755 \\
\hline $\begin{array}{l}\text { USGS Person } \\
\text { County identifi- } \\
\text { cation number } \\
\text { (fig. 2) }\end{array}$ & $\begin{array}{c}\text { USGS site } \\
\text { identification number }\end{array}$ & Period of drilling & $\begin{array}{l}\text { Well depth } \\
\text { (ft bls) }\end{array}$ & $\begin{array}{l}\text { Depth to bottom } \\
\text { of casing } \\
\text { (ft bls) }\end{array}$ & $\begin{array}{c}\text { Land-surface } \\
\text { altitude } \\
\text { (feet above } \\
\text { NAVD 88) }\end{array}$ \\
\hline PS-108 & 362455078563101 & $1 / 14 / 2013$ & 150 & 46 & 750 \\
\hline PS-109 & 362502078563201 & $1 / 10 / 2013-1 / 11 / 2013$ & 200 & 41 & 748 \\
\hline PS-111 & 362500078563001 & $1 / 15 / 13-1 / 17 / 13$ & 150 & 34 & 753 \\
\hline PS-112 & 362459078562801 & $12 / 8 / 2012-12 / 9 / 2012$ & 150 & 40 & 753 \\
\hline
\end{tabular}




\section{References Cited}

Advanced Logic Technology, 2010, WellCad ${ }^{\mathrm{TM}}$ : Advanced Logic Technology (aLt) Web page, accessed February 2015 at http://www.alt.lu/software.htm.

Antolino, D.J., and Chapman, M.J., 2016, Continued geophysical logging in the vicinity of the GMH Electronics Superfund site near Roxboro, North Carolina: U.S. Geological Survey data release, accessed December 27, 2016, at http://dx.doi.org/10.5066/F7FX77JP.

Briggs, D.F., Gilbert, M.C., and Glover, L., III, 1978, Petrology and regional significance of the Roxboro metagranite, North Carolina: Geological Society of America Bulletin 1978, v. 89, p. 511-521.

Chapman, M.J., Bolich, R.E., and Huffman, B.A., 2005, Hydrogeologic setting, ground-water flow, and groundwater quality at the Lake Wheeler Road research station, 2001-03 - North Carolina Piedmont and Mountains Resource Evaluation Program: U.S. Geological Survey Scientific Investigations Report 2005-5166, 85 p. [Also available at http://pubs.usgs.gov/sir/2005/5166/.]

Chapman, M.J., Clark, T.W., and Williams, J.H., 2013, Geophysical logging and geologic mapping data in the vicinity of the GMH Electronics Superfund site near Roxboro, North Carolina: U.S. Geological Survey Data Series 762, 35 p., accessed September 7, 2016, at http://pubs.usgs.gov/ds/762/.

Day-Lewis, F.D., Johnson, C.D., Paillet, F.L., and Halford, K.J., 2011, A computer program for flow-log analysis of single holes (FLASH): Groundwater, v. 49, no. 6, p. 926-931. [Also available at http://dx.doi.org/10.1111/ j.1745-6584.2011.00798.x.]

Heath, R.C., 1980, Basic elements of ground-water hydrology with reference to conditions in North Carolina: U.S. Geological Survey Open-File Report 80-44, 86 p. [Also available at https://pubs.usgs.gov/of/1980/0044/report.pdf.]

Heath, R.C., 1983, Basic ground-water hydrology: U.S. Geological Survey Water-Supply Paper 2220, 84 p. [Also available at http://pubs.usgs.gov/wsp/2220/report.pdf.]

Heath, R.C., 1984, Ground-water regions of the United States: U.S. Geological Survey Water-Supply Paper 2242, 78 p. [Also available at http://pubs.usgs.gov/wsp/wsp2242/pdf/ wsp2242.pdf.]

Heath, R.C., 1994, Ground-water recharge in North Carolina: Raleigh, North Carolina Department of Environment, Health, and Natural Resources, Groundwater Section, Open-File Report, 52 p.
Hibbard, J.P., Stoddard, E.F., Secor, D.T., and Dennis, A.J., 2002, The Carolina Zone-Overview of Neoproterozoic to Early Paleozoic peri-Gondwanan terranes along the eastern flank of the southern Appalachians: Earth Science Reviews, v. 57, nos. 3-4, p. 299-339. [Also available at http://dx.doi.org/ 10.1016/S0012-8252(01)00079-4.]

Huffman, B.A., Pfeifle, C.A., Chapman, M.J., Bolich, R.E., Campbell, T.R., Geddes, D.J., Jr., and Pippin, C.G., 2006, Compilation of water-resources data and hydrogeologic setting for four research stations in the Piedmont and Blue Ridge Physiographic Provinces of North Carolina, 2000-2004: U.S. Geological Survey Open-File Report 2006-1168, 102 p., accessed September 7, 2016, at https://pubs.usgs.gov/of/2006/1168/.

McSwain, K.B., Bolich, R.E., and Chapman, M.J., 2013, Hydrogeology, groundwater seepage, nitrate distribution, and flux at the Raleigh Hydrogeologic Research Station, Wake County, North Carolina, 2005-2007: U.S. Geological Survey Scientific Investigations Report 2013-5041, 54 p., accessed March 2015 at http://pubs.usgs.gov/ sir/2013/5041/.

McSwain, K.B., Bolich, R.E., Chapman, M.J., and Huffman, B.A., 2008, Water-resources data and hydrogeologic setting at the Raleigh Hydrogeologic Research Station, Wake County, North Carolina, 2005-2007: U.S. Geological Survey OpenFile Report 2008-1377, 48 p., accessed March 2015 at http://pubs.water.usgs.gov/ofr2008-1377.

National Oceanic and Atmospheric Administration, 2015, Magnetic field calculators-Magnetic declination estimated value: National Oceanic and Atmospheric Administration, National Centers for Environmental Information Web page, accessed October 2015 at https://www.ngdc.noaa.gov/ geomag-web/\#declination.

North Carolina Geological Survey, 1985, Geologic map of North Carolina: Raleigh, North Carolina Geological Survey, scale 1:500,000.

Pippin, C.G., Chapman, M.J., Huffman, B.A., Heller, M.J., and Schelgel, M.E., 2008, Hydrogeologic setting, groundwater flow, and ground-water quality at the Langtree Peninsula research station, Iredell County, North Carolina, 2000-2005: U.S. Geological Survey Scientific Investigations Report 2008-5055, 89 p., accessed March 2015 at http://pubs.water.usgs.gov/sir2008-5055.

Rockware, Inc., 2010, RockWorks earth science and GIS software: Rockware, Inc., accessed September 15, 2014, at http://www.rockware.com/.

Srivastav, S.K., Lubexynski, M.W., and Biyani, A.K., 2007, Upscaling of transmissivity, derived from specific capacityA hydrogeomorphological approach applied to the Doon Valley aquifer system in India: Hydrogeology Journal, v. 15, p. 1251-1264. [Also available at http://dx.doi.org/10.1007/ s10040-007-0207-8.] 



\section{Appendix 1. Borehole Geophysical Image Logs Showing Orientations of Subsurface Structural Features}




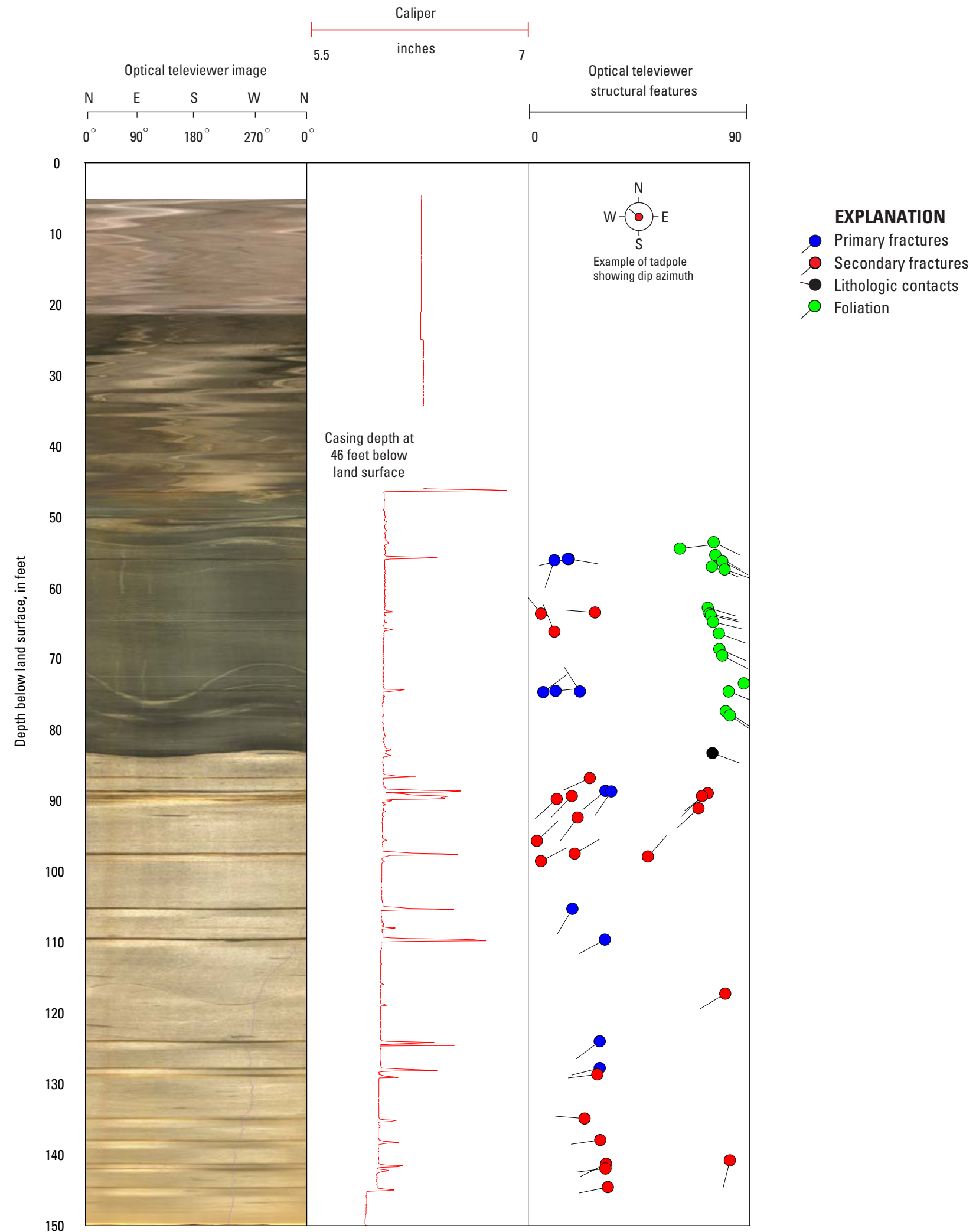

Figure 1-1. Optical televiewer image and structural orientations of subsurface features in well PS-108, near the GMH Electronics National Priorities List Superfund site, Roxboro, Person County, North Carolina. 


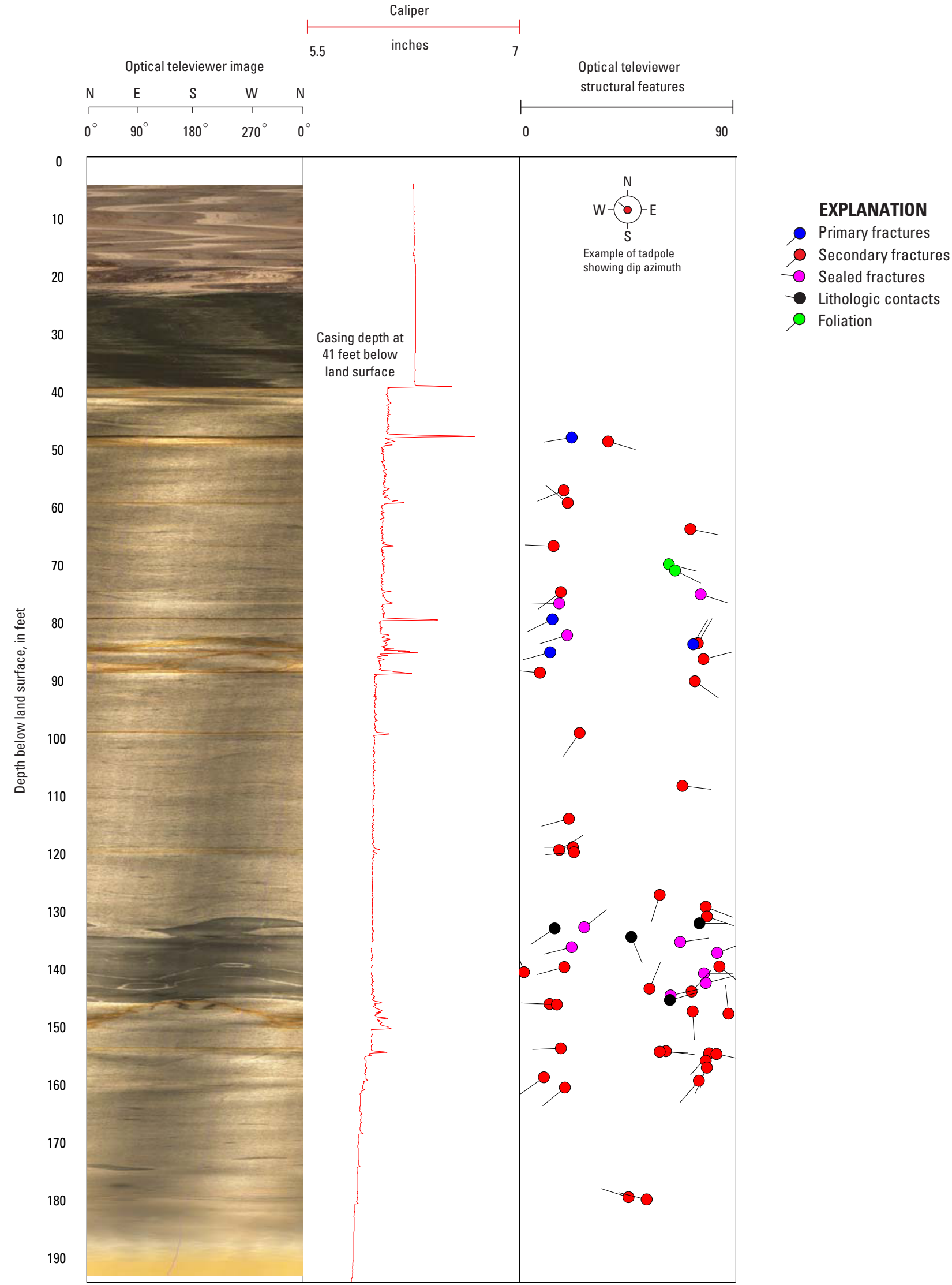

Figure 1-2. Optical televiewer image and structural orientations of subsurface features in well PS-109, near the GMH Electronics National Priorities List Superfund site, Roxboro, Person County, North Carolina. 


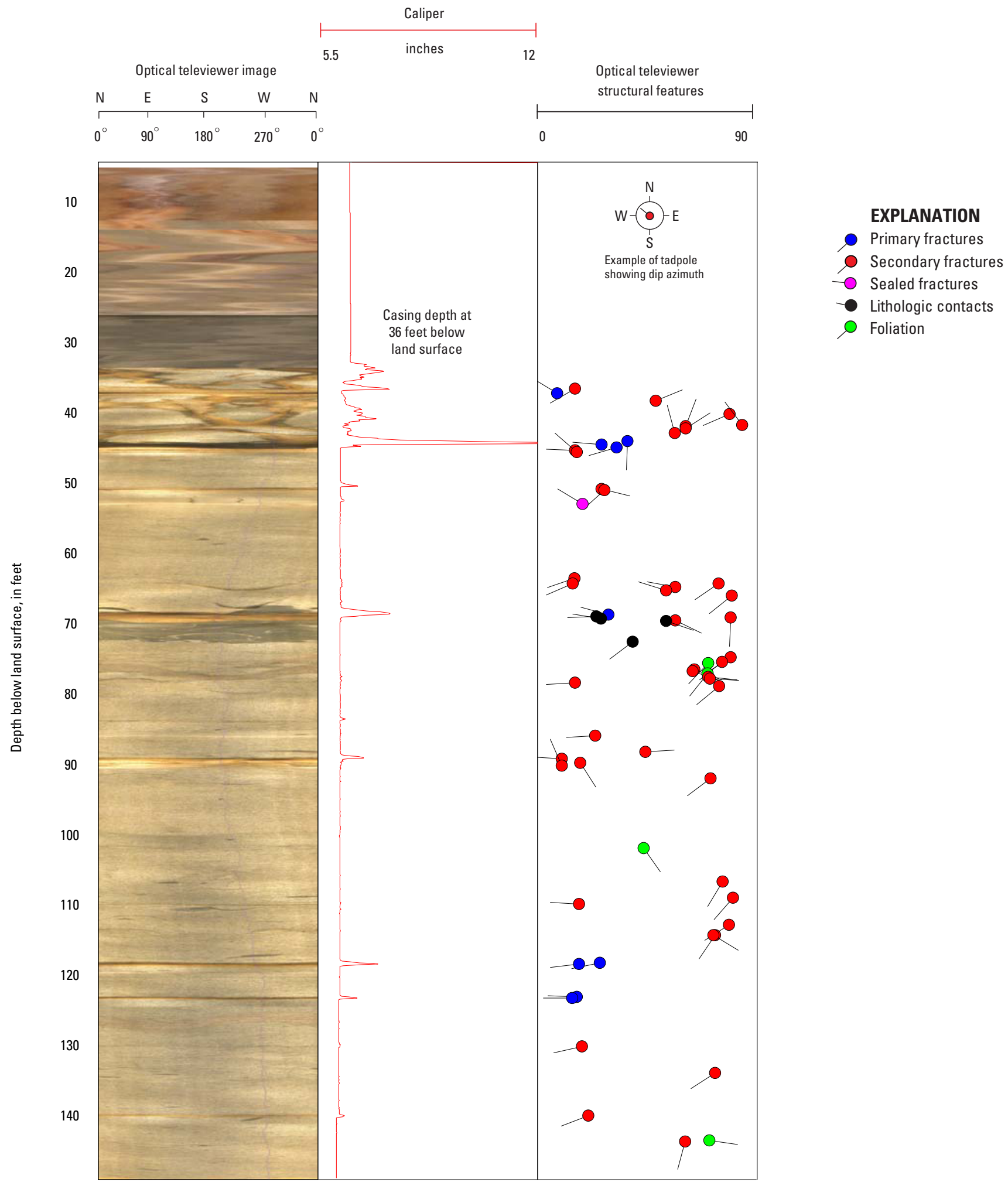

Figure 1-3. Optical televiewer image and structural orientations of subsurface features in well PS-111, near the GMH Electronics National Priorities List Superfund site, Roxboro, Person County, North Carolina. 


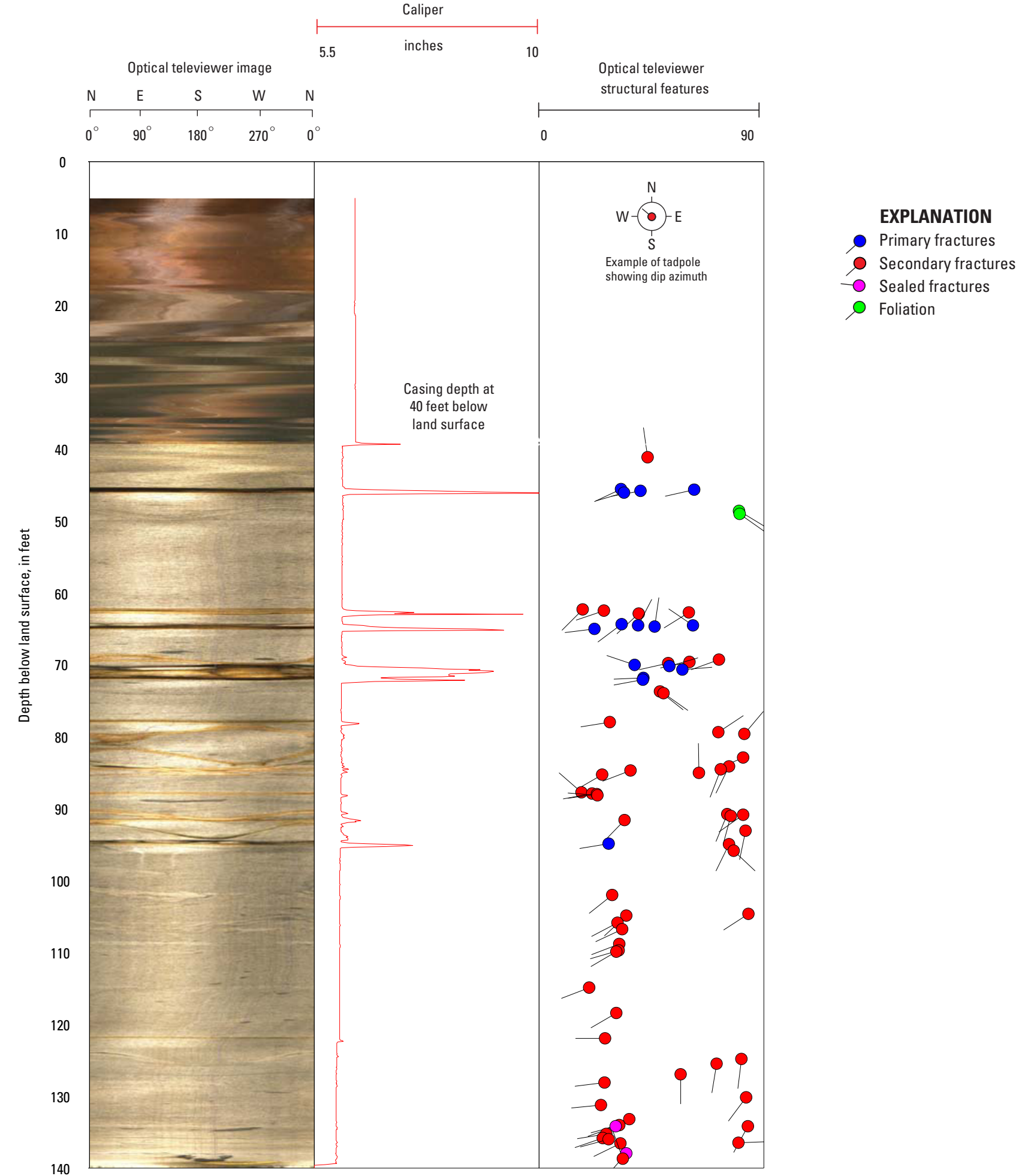

Figure 1-4. Optical televiewer image and structural orientations of subsurface features in well PS-112, near the GMH Electronics National Priorities List Superfund site, Roxboro, Person County, North Carolina. 


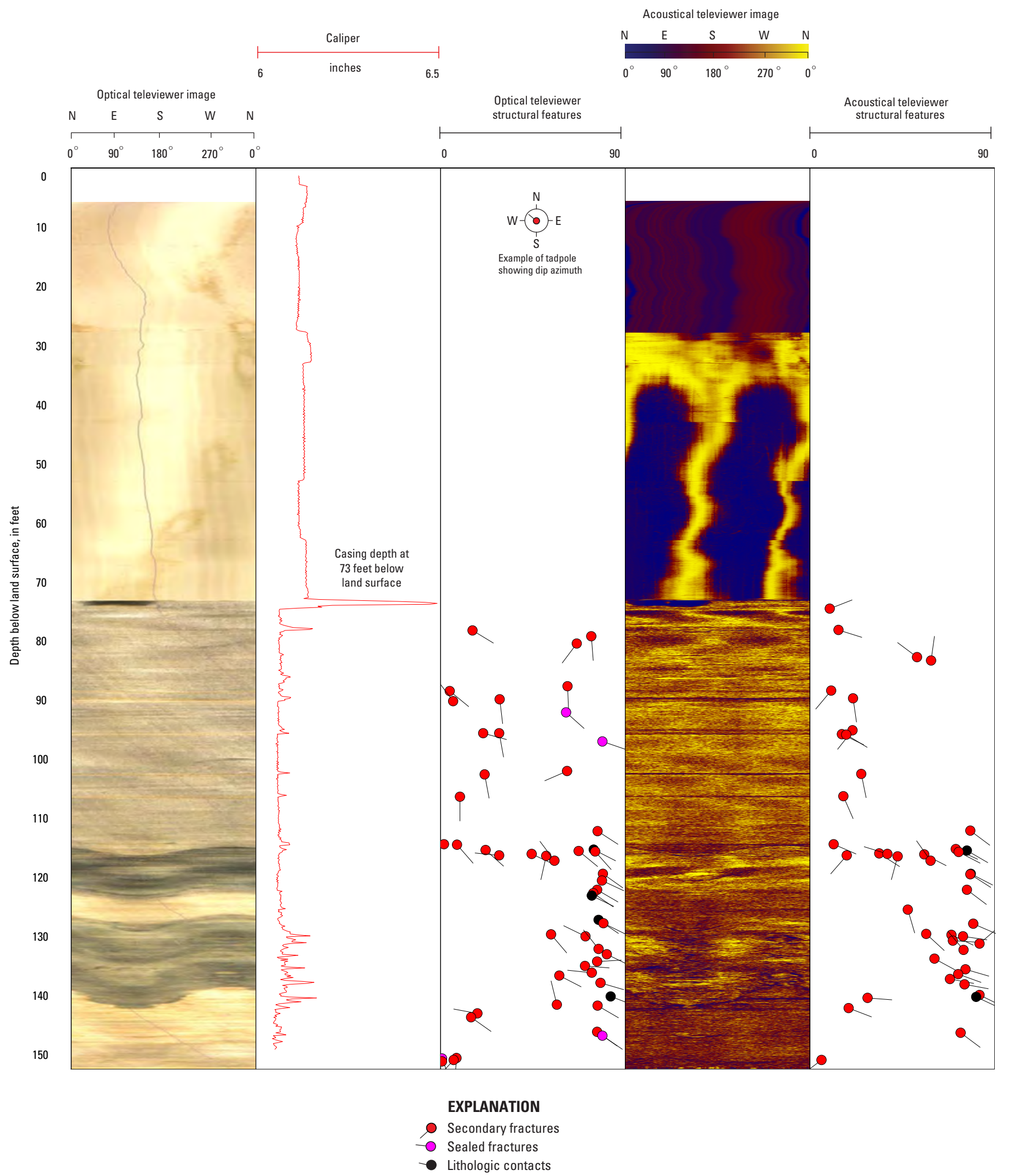

Figure 1-5. Optical and acoustical televiewer images and structural orientations of subsurface features in well PS-114, near the GMH Electronics National Priorities List Superfund site, Roxboro, Person County, North Carolina. 


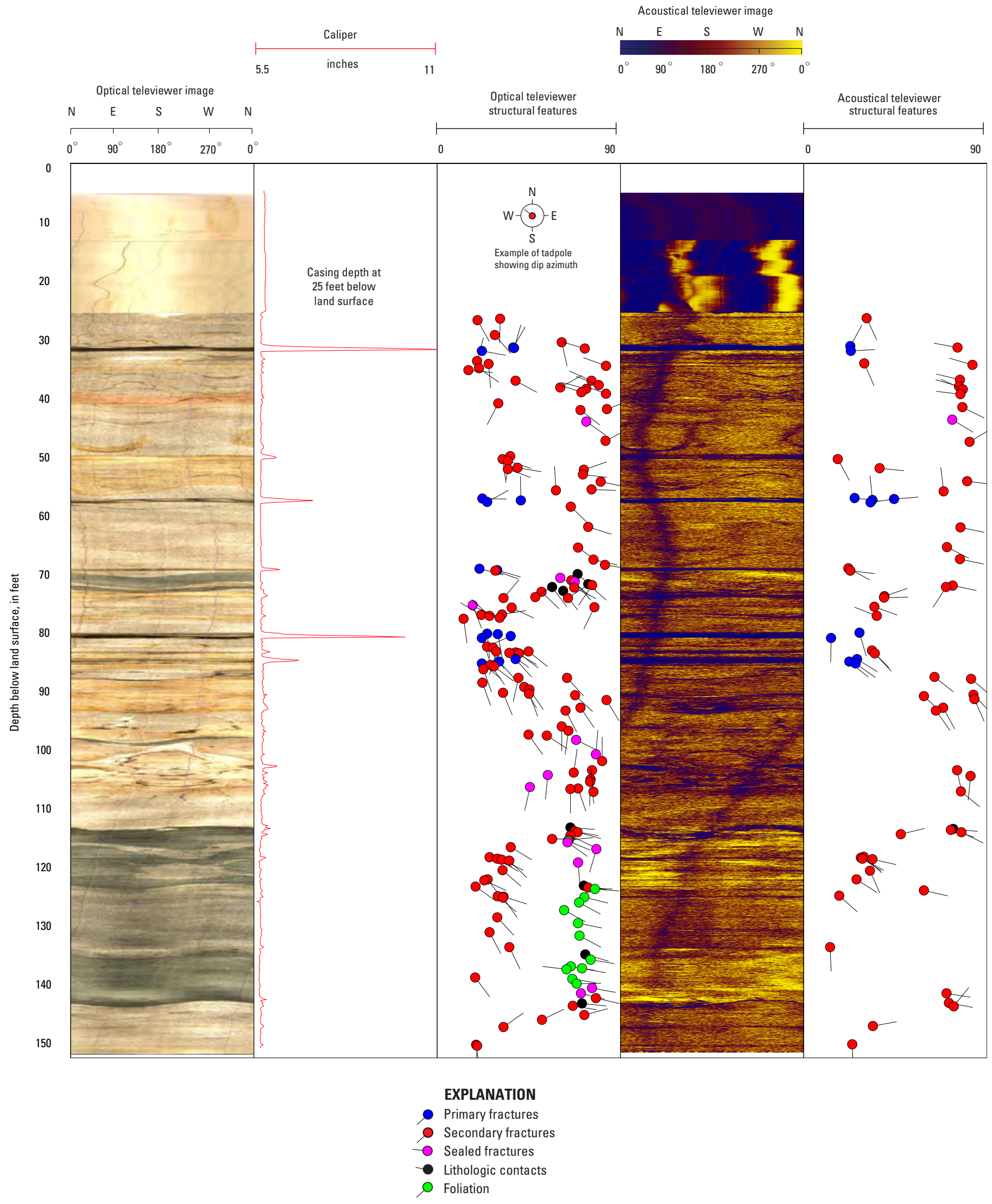

Figure 1-6. Optical and acoustical televiewer images and structural orientations of subsurface features in well PS-115, near the GMH Electronics National Priorities List Superfund site, Roxboro, Person County, North Carolina. 


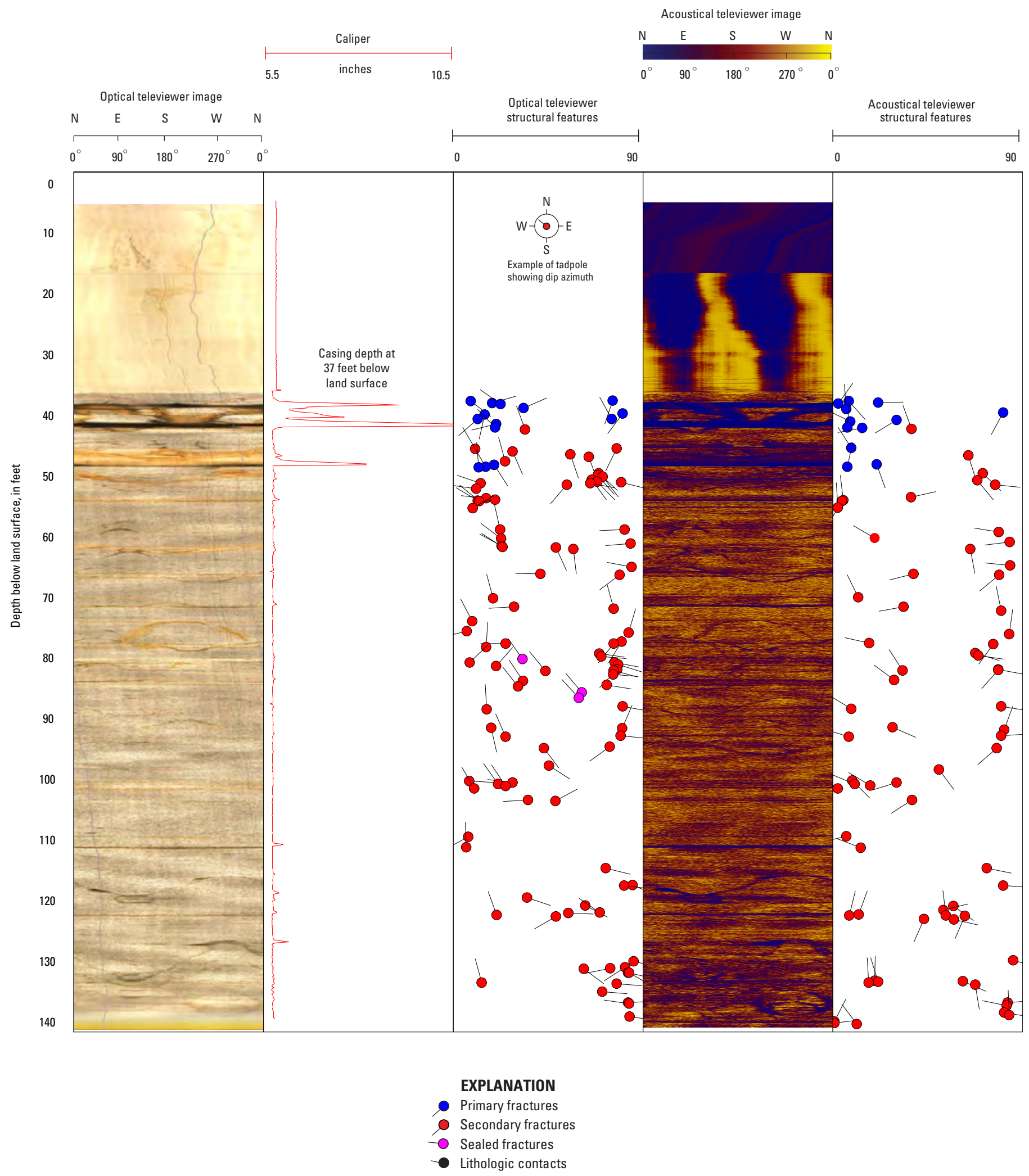

Figure 1-7. Optical and acoustical televiewer images and structural orientations of subsurface features in well PS-116, near the GMH Electronics National Priorities List Superfund site, Roxboro, Person County, North Carolina. 


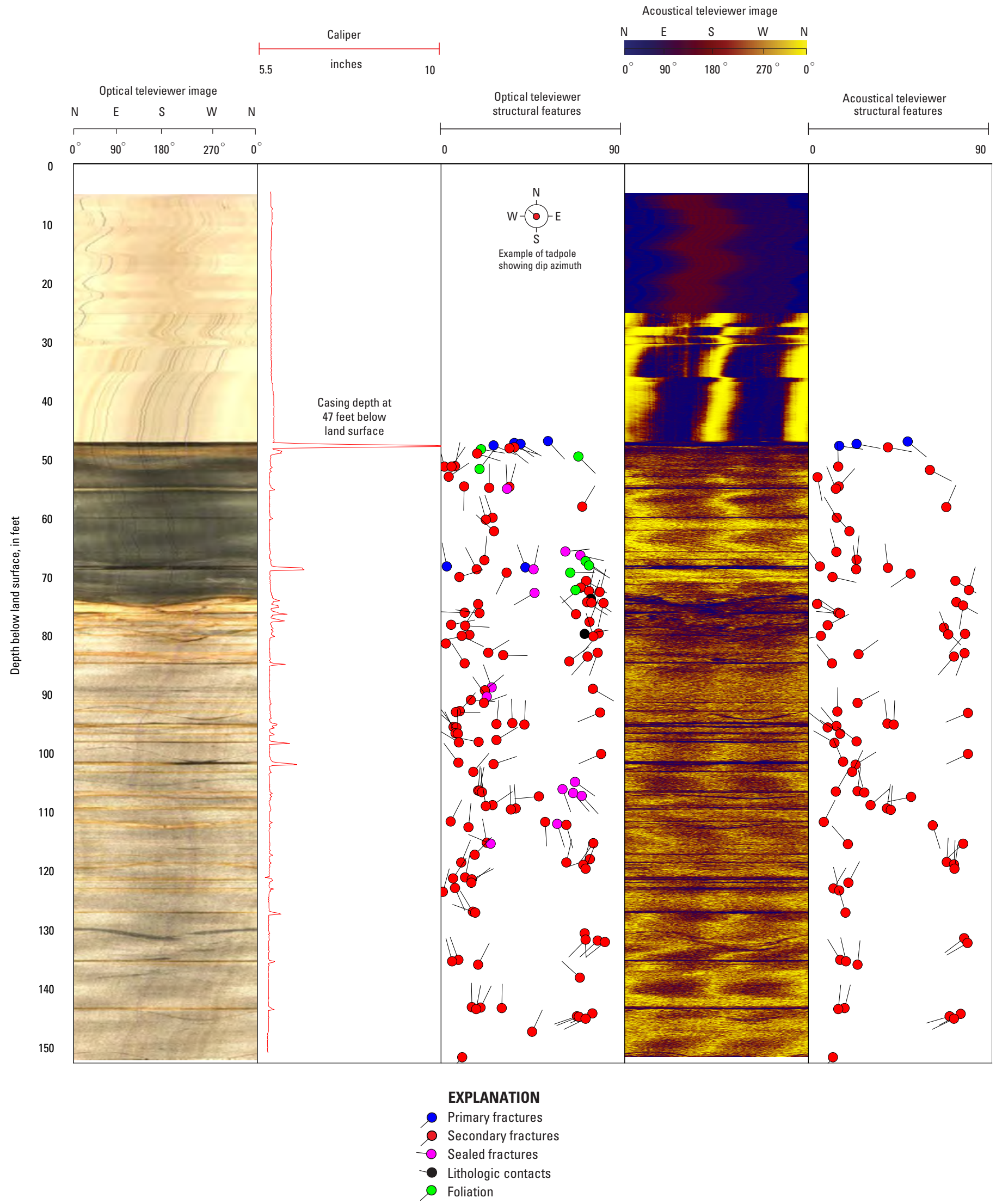

Figure 1-8. Optical and acoustical televiewer images and structural orientations of subsurface features in well PS-117, near the GMH Electronics National Priorities List Superfund site, Roxboro, Person County, North Carolina. 


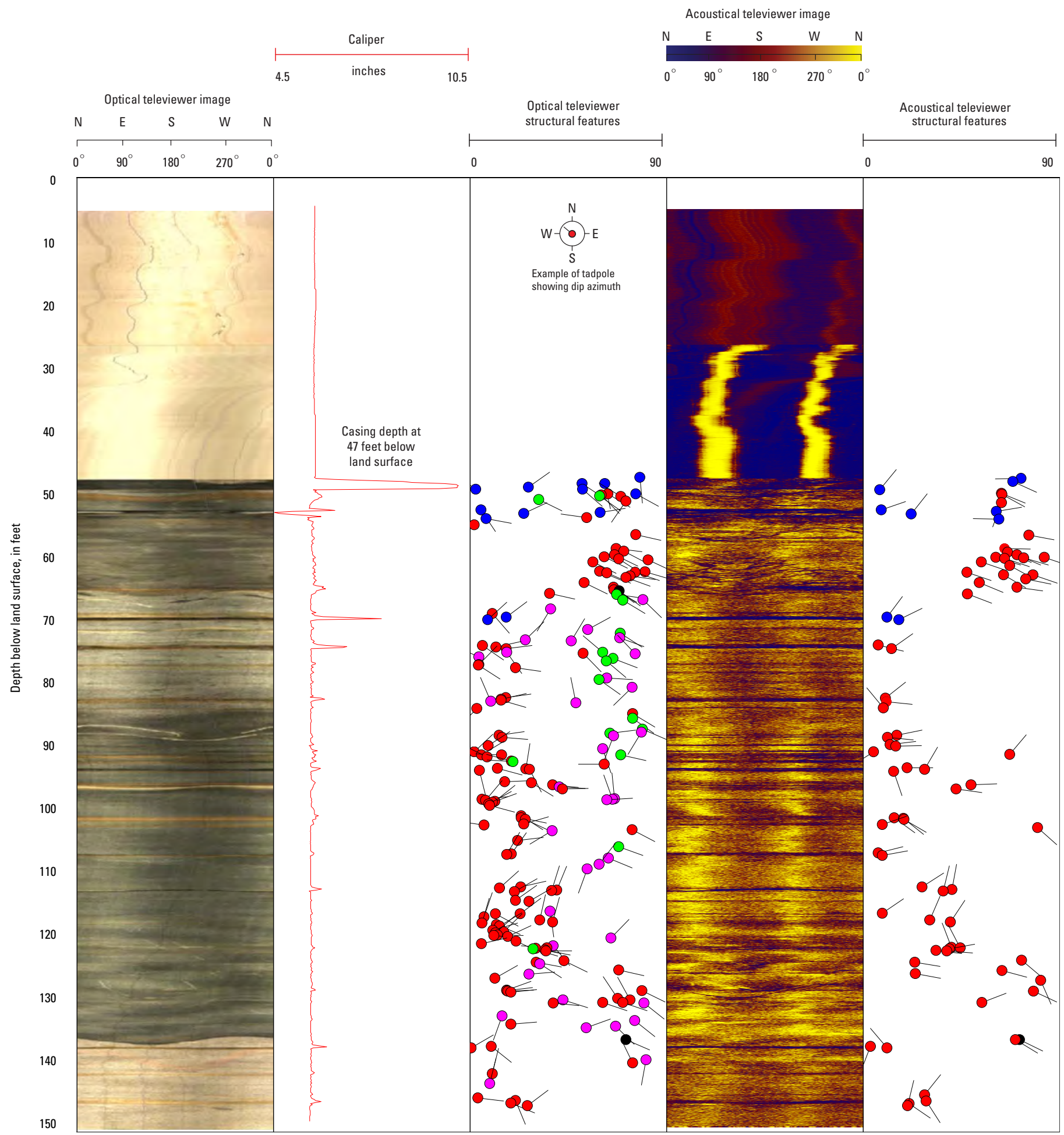

EXPLANATION

- Primary fractures

Secondary fractures

- Sealed fractures

- Lithologic contacts

○ Foliation

Figure 1-9. Optical and acoustical televiewer images and structural orientations of subsurface features in well PS-118, near the GMH Electronics National Priorities List Superfund site, Roxboro, Person County, North Carolina. 


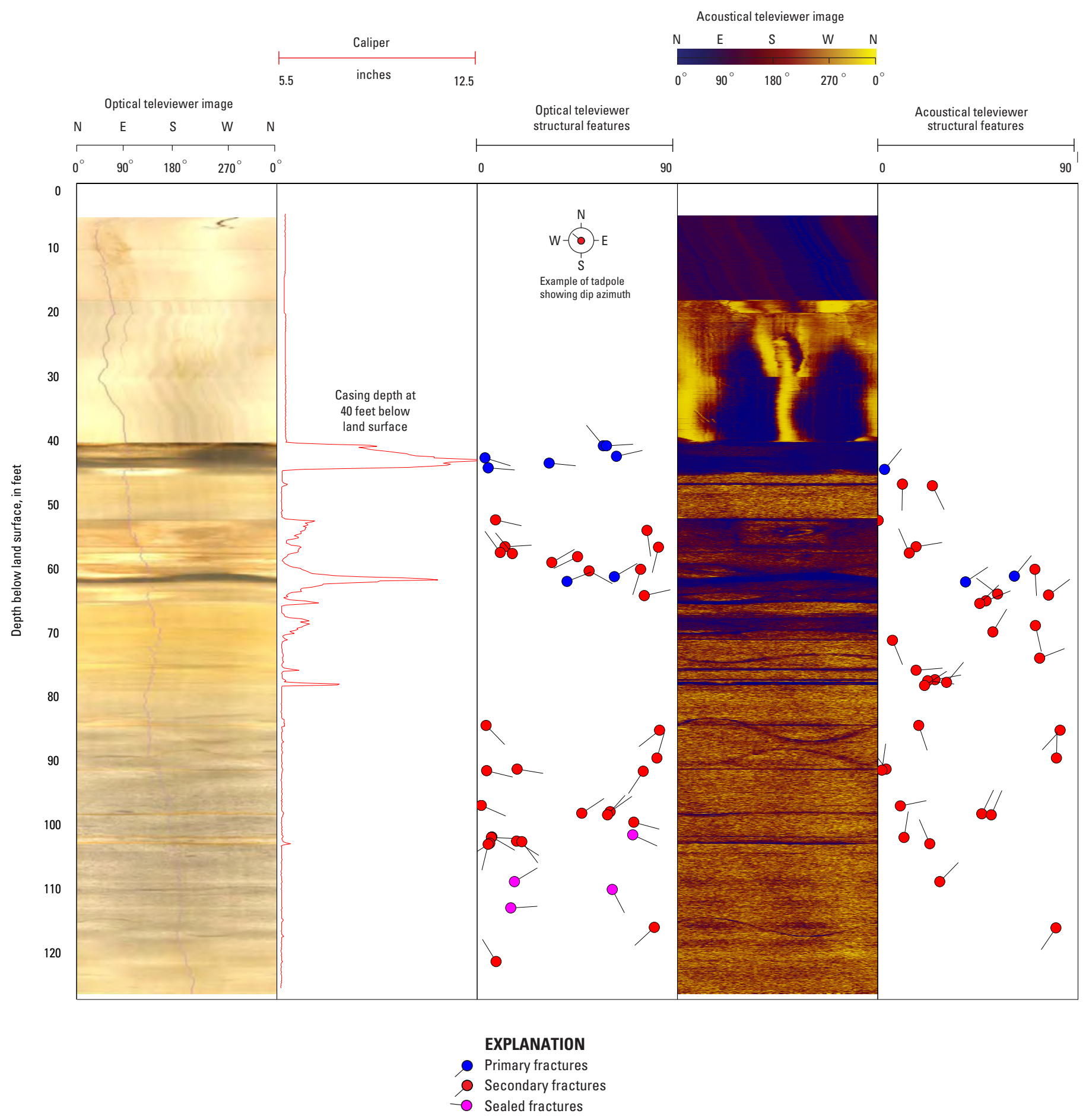

Figure 1-10. Optical and acoustical televiewer images and structural orientations of subsurface features in well PS-119, near the GMH Electronics National Priorities List Superfund site, Roxboro, Person County, North Carolina. 



\section{Appendix 2. Borehole Geophysical Logs Showing Depth of Fracture Zones and Measured Borehole Flow}




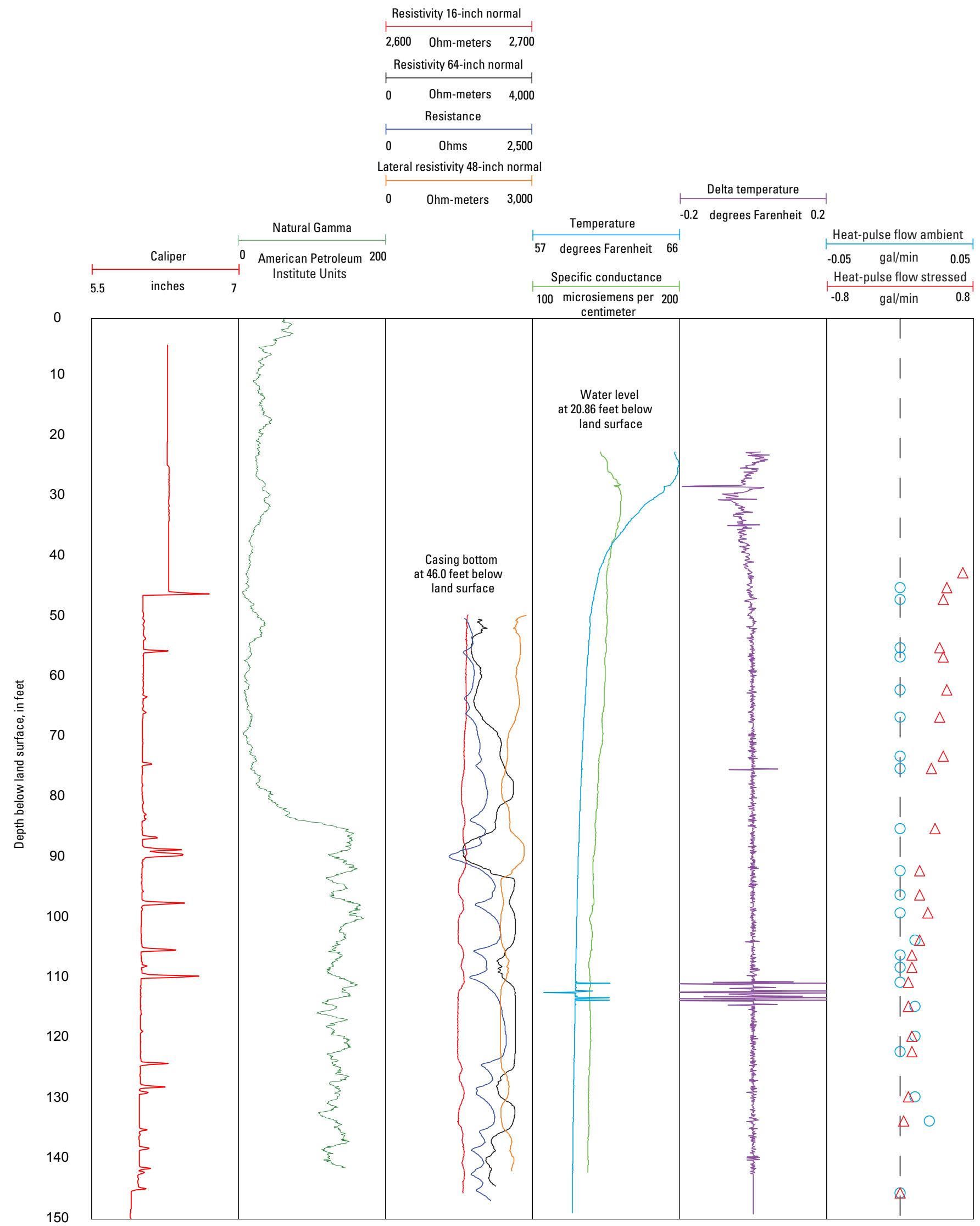

Figure 2-1. Borehole geophysical logs showing depth of fracture zones and borehole flow in well PS-108, near the GMH Electronics National Priorities List Superfund site, Roxboro, Person County, North Carolina. 


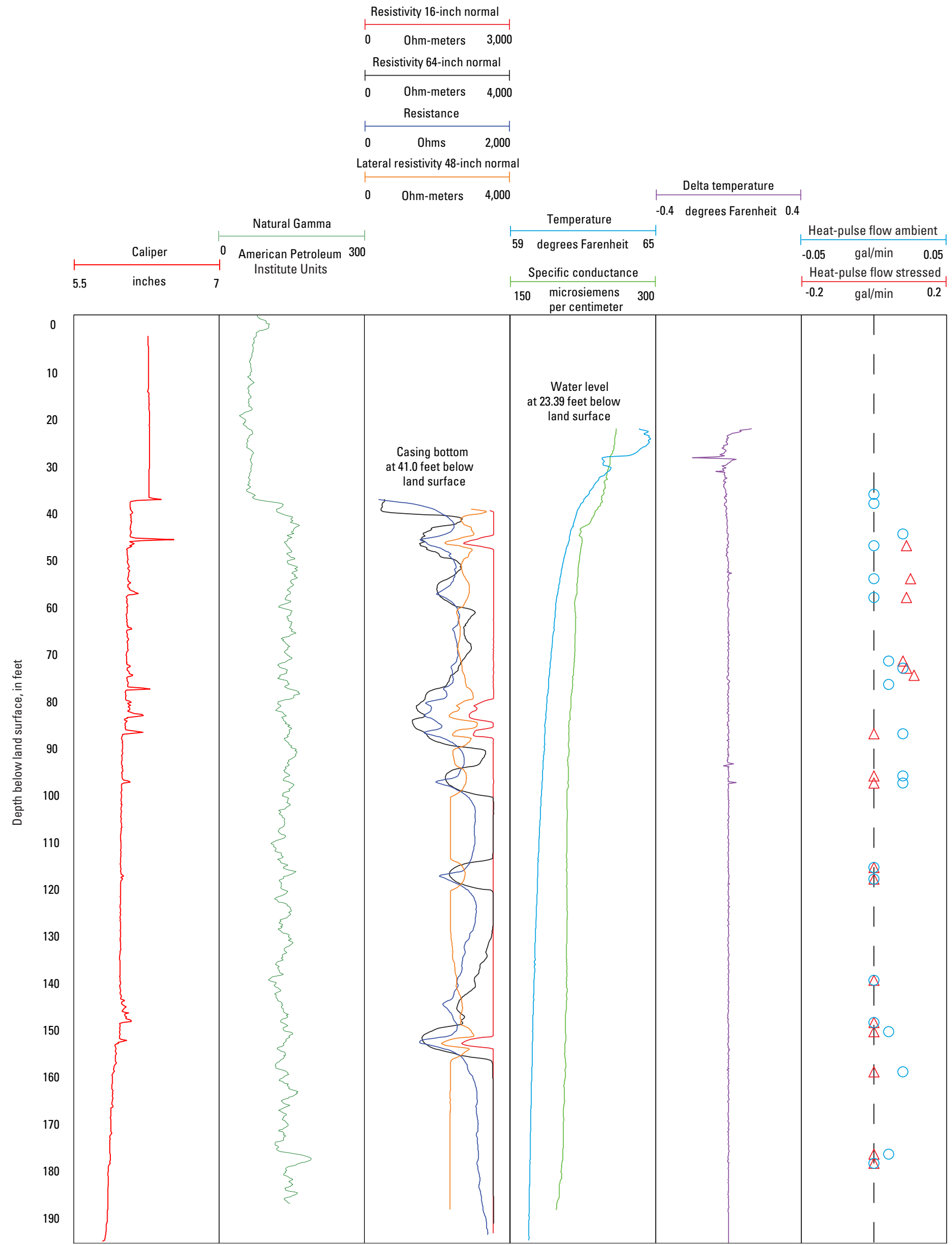

Figure 2-2. Borehole geophysical logs showing depth of fracture zones and borehole flow in well PS-109, near the GMH Electronics National Priorities List Superfund site, Roxboro, Person County, North Carolina. 


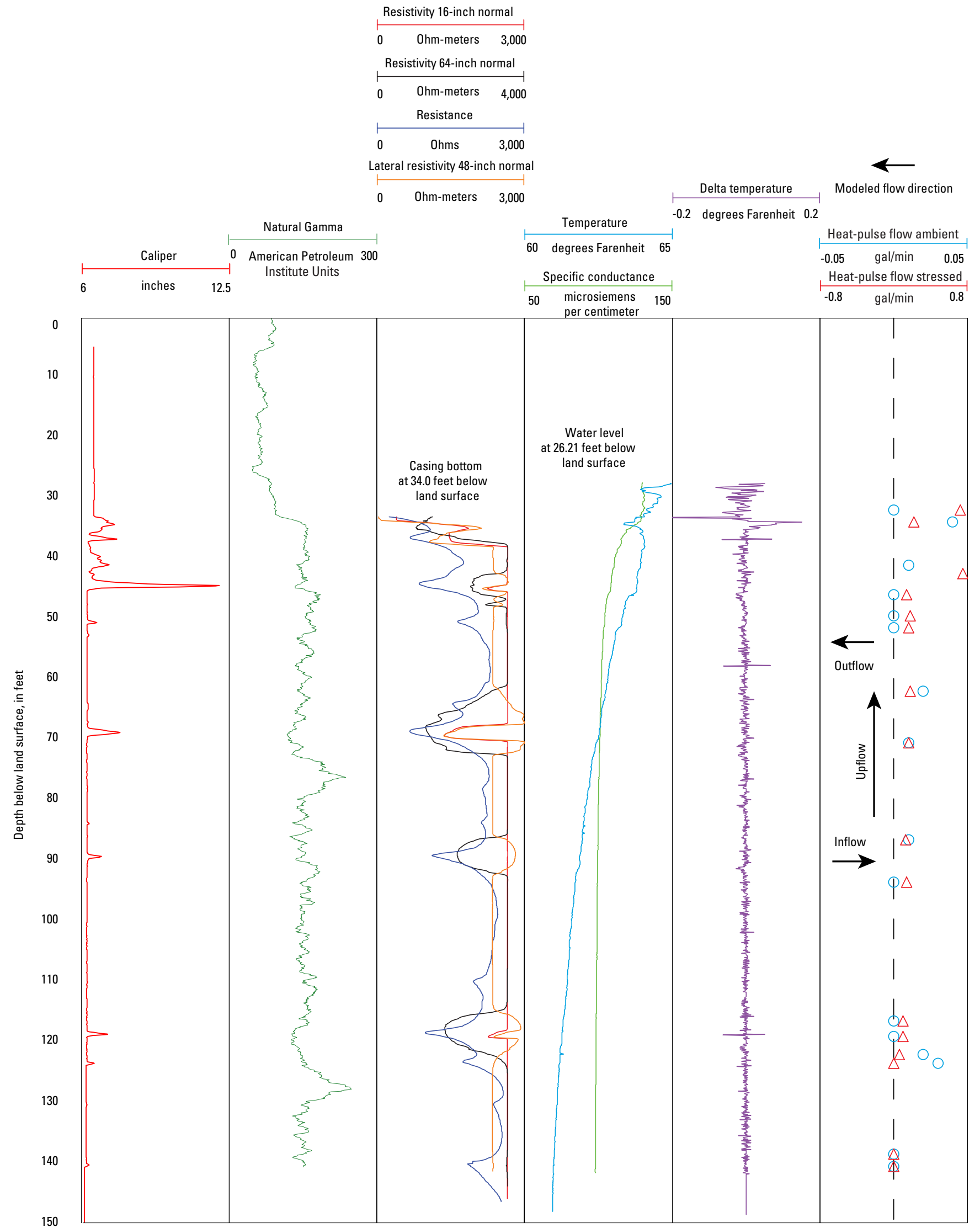

Figure 2-3. Borehole geophysical logs showing depth of fracture zones and borehole flow in well PS-111, near the GMH Electronics National Priorities List Superfund site, Roxboro, Person County, North Carolina. 


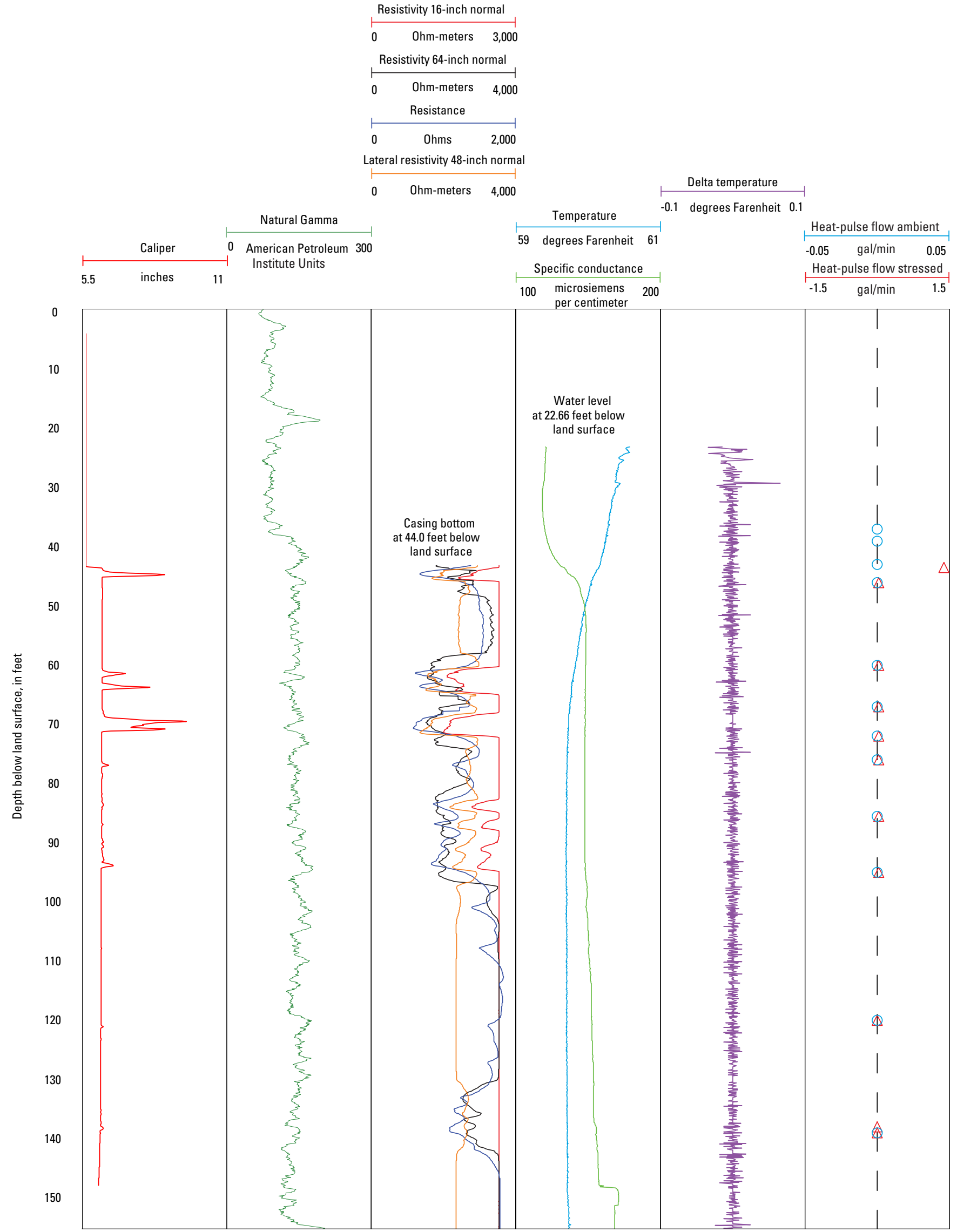

Figure 2-4. Borehole geophysical logs showing depth of fracture zones and borehole flow in well PS-112, near the GMH Electronics National Priorities List Superfund site, Roxboro, Person County, North Carolina. 


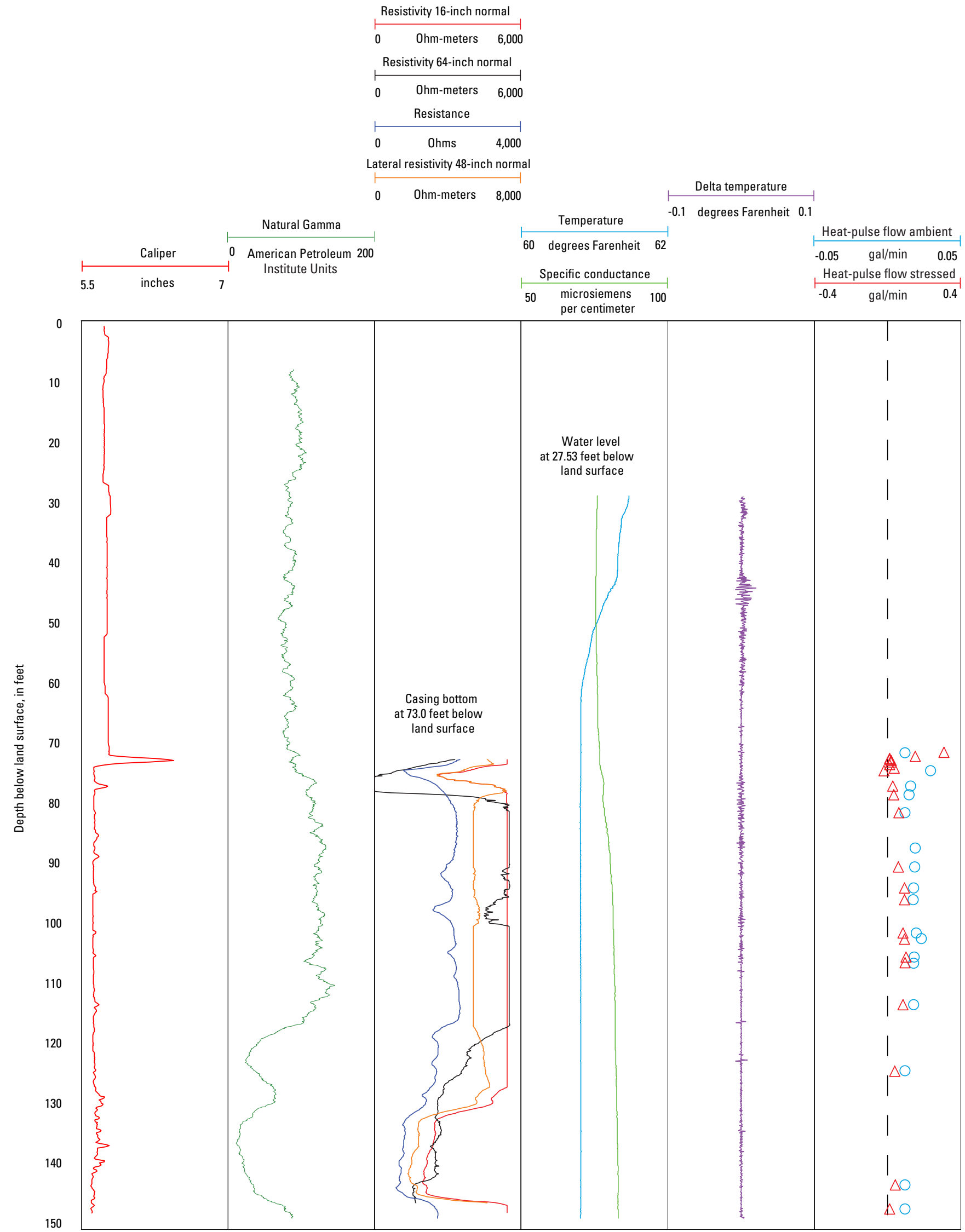

Figure 2-5. Borehole geophysical logs showing depth of fracture zones and borehole flow in well PS-114, near the GMH Electronics National Priorities List Superfund site, Roxboro, Person County, North Carolina. 


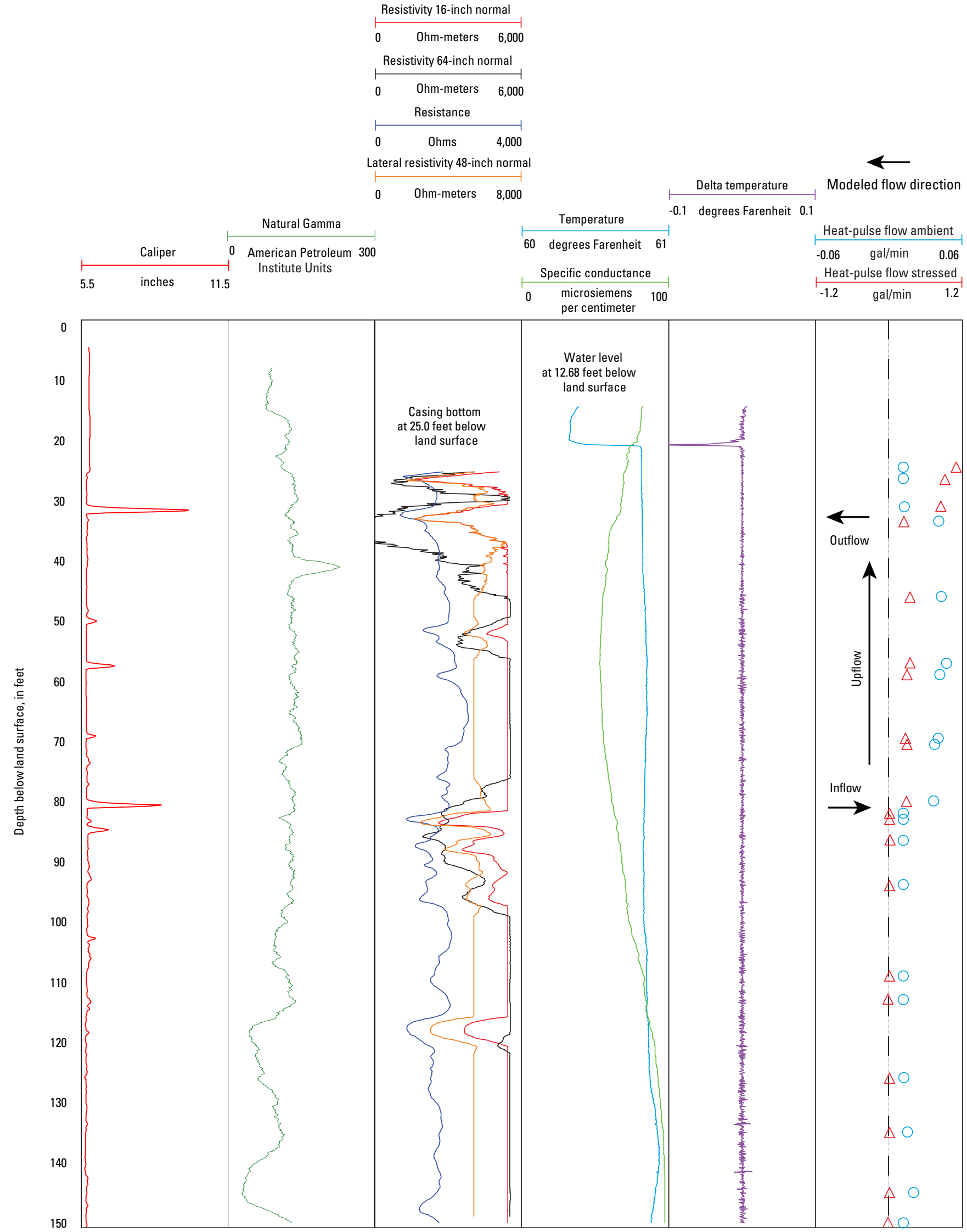

Figure 2-6. Borehole geophysical logs showing depth of fracture zones and borehole flow in well PS-115, near the GMH Electronics National Priorities List Superfund site, Roxboro, Person County, North Carolina. 


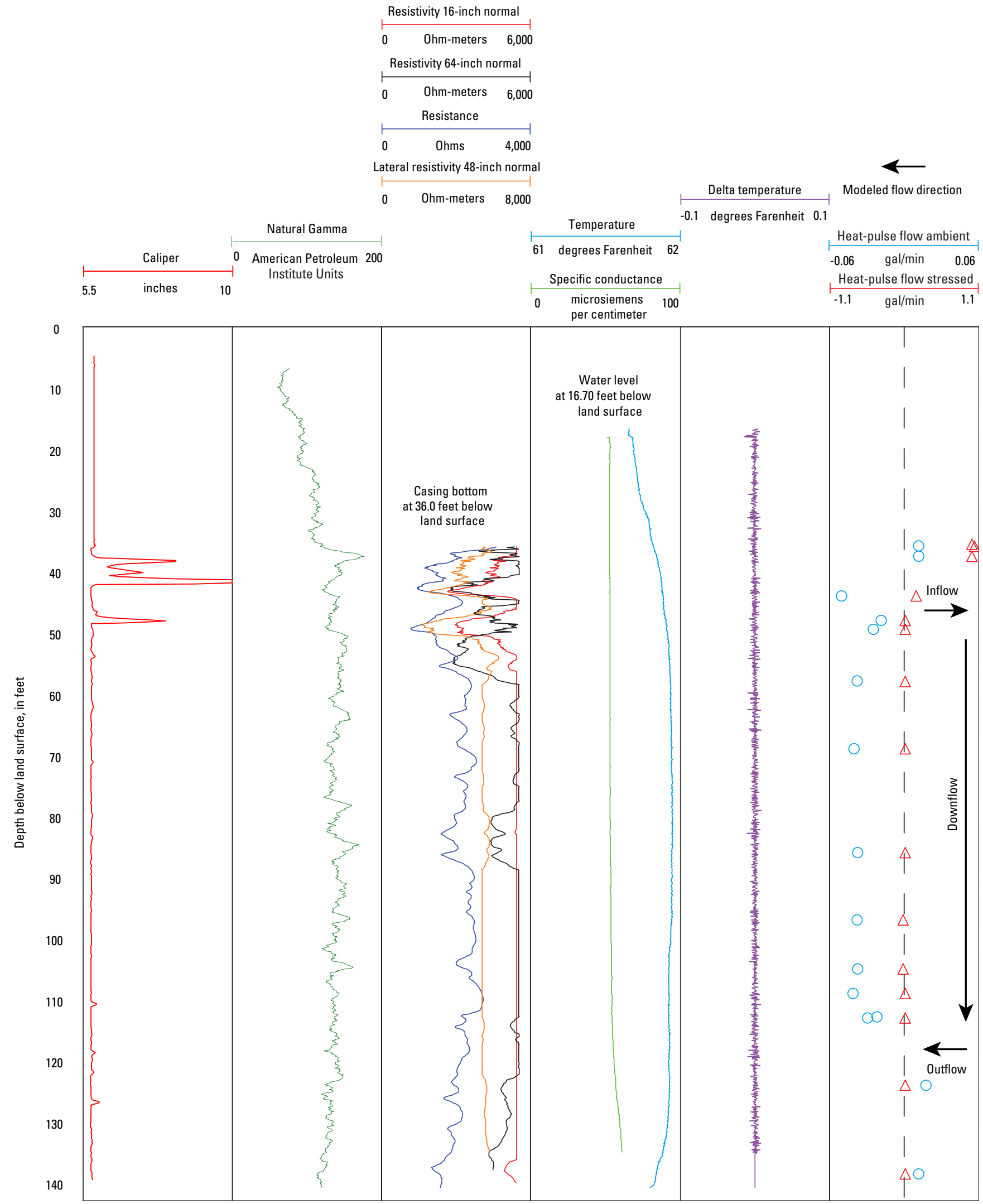

Figure 2-7. Borehole geophysical logs showing depth of fracture zones and borehole flow in well PS-116, near the GMH Electronics National Priorities List Superfund site, Roxboro, Person County, North Carolina. 


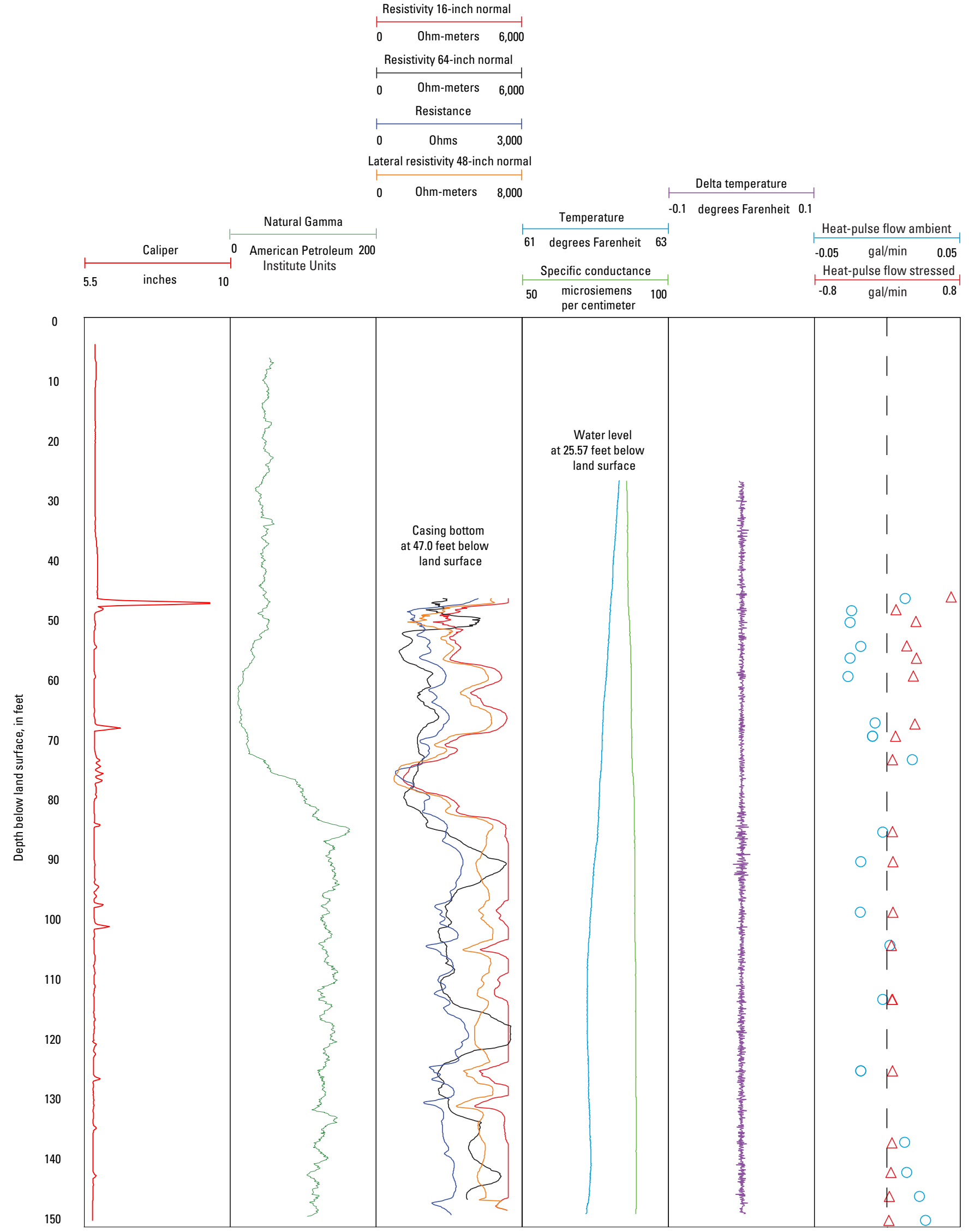

Figure 2-8. Borehole geophysical logs showing depth of fracture zones and borehole flow in well PS-117, near the GMH Electronics National Priorities List Superfund site, Roxboro, Person County, North Carolina. 


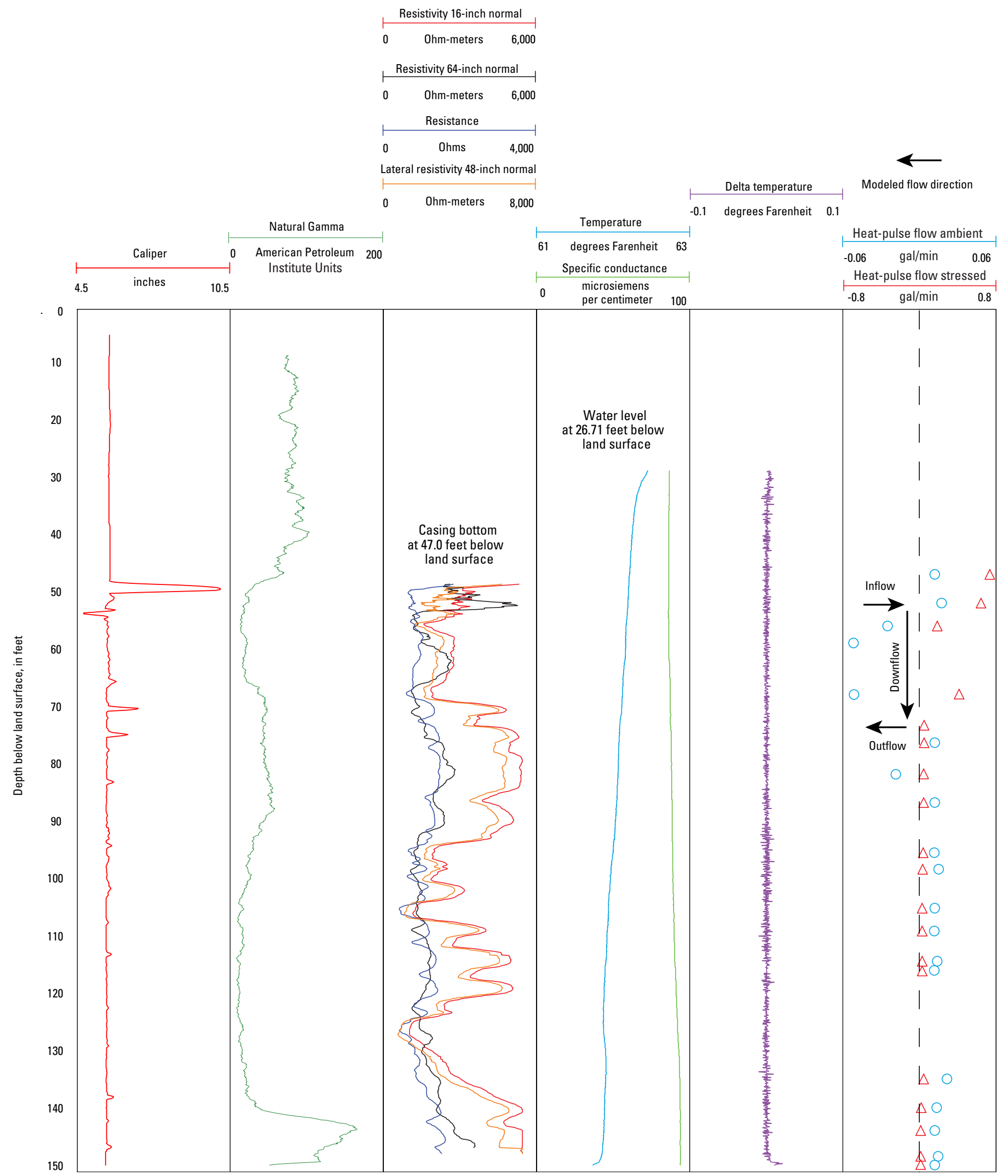

Figure 2-9. Borehole geophysical logs showing depth of fracture zones and borehole flow in well PS-118, near the GMH Electronics National Priorities List Superfund site, Roxboro, Person County, North Carolina. 


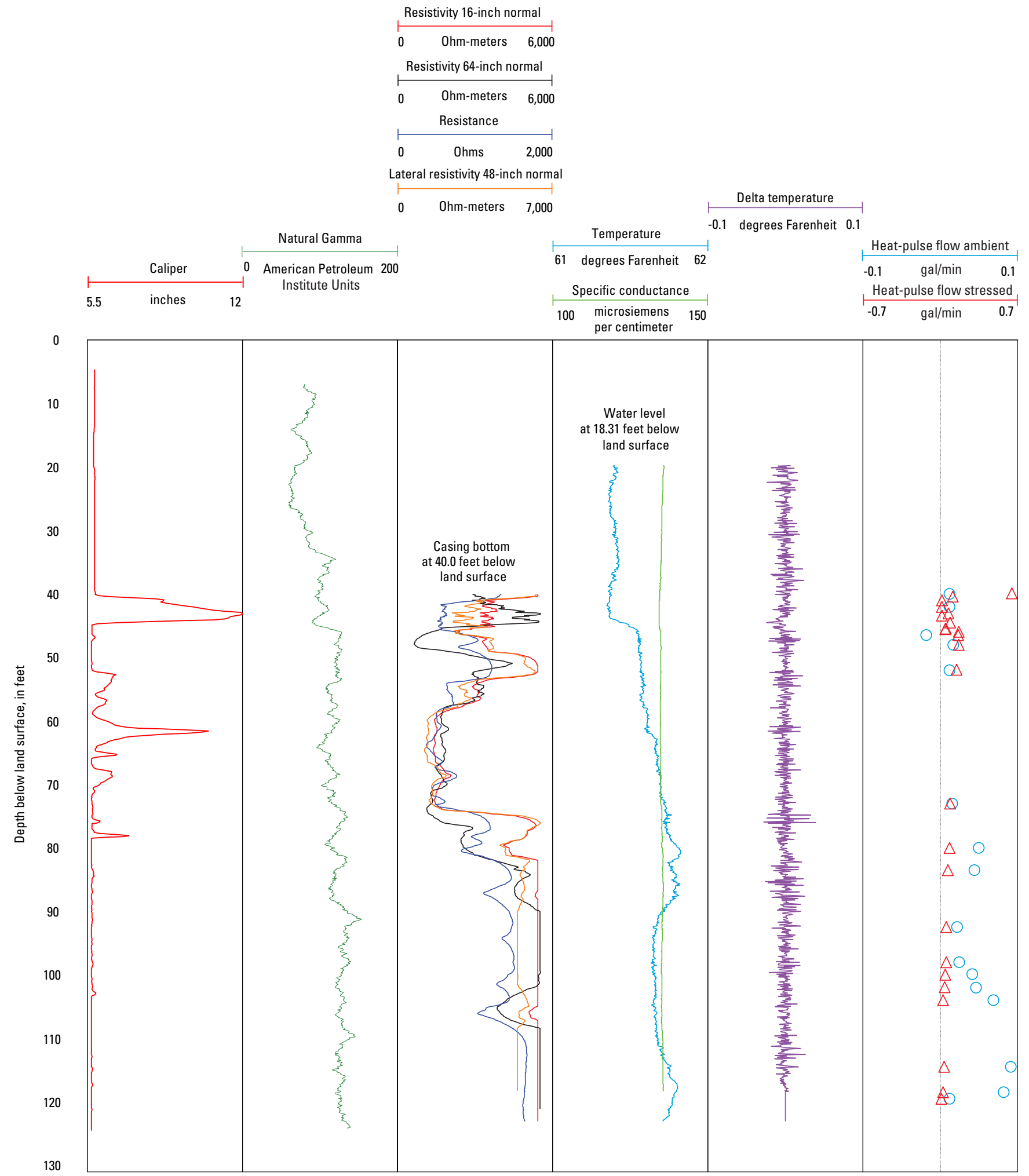

Figure 2-10. Borehole geophysical logs showing depth of fracture zones and borehole flow in well PS-119, near the GMH Electronics National Priorities List Superfund site, Roxboro, Person County, North Carolina. 

Manuscript approved September 27, 2016

Prepared by the USGS Science Publishing Network

For additional information regarding this publication, please contact:

Director, South Atlantic Water Science Center

U.S. Geological Survey

720 Gracern Road

Stephenson Center, Suite 129

Columbia, SC 29210

(803) $750-6100$

Or visit the South Atlantic Water Science Center Web site at

http://www.usgs.gov/water/southatlantic/ 
